\title{
EXPERIMENTAL STUDIES OF FORCES ON PILES
}

\author{
by \\ J. R. Morison, J.W. Johnson and M.P. O'Brion \\ Department of Engineoring, Oniversity of Callfornia \\ Berkeley, Callf.
}

\section{INTRODUCTIOH}

In the design of a pile struoture exposed to surface waves of a given height and period, some of the faotors involved in the problem and studied hereln are the size, shape and spacing of the piles and the momont distribution on uniform and non-untform pllos. Theoretical and oxperimental investigations have shown that the force exerted by surface waves on a pile consists of two components -- a drag foroe and an inortia foroe. The drag foroe is proportional to the fluld density, the projeoted area and the square of the fluid particle volooity. The inortia forco, including the virtual mass, 18 proportional to the fluid density, the volume of the objeot and the fluid particle accoleration. The virtual mass is the apparent inorease of the displacod mass of fluid necessary to acoount for the inoresse in foroe resulting from the aoooleration of the fluid relative to the objeot. This faotor is included in the coeffioient of mass term in the foros oalculations.

The experimental and analytical approaches to the pile problem presented in this paper have been based on the total moment about the bottom of the pile and the moment distribution over the length of the pilo. In order to calculate theoretical moment it is necessary to obtain from the experimental results two ompirioal coefficients -- a drag coofficient and a mas coofflotent (Morison, O'Brien, Johnson and Sohaaf, 1950). The theoretioal oquations of total moment corresponding to the orest, trough, and still-water lovel positions along the surface wave are used to oompute these coefficlents from the measured total moments at the same positions. Using these cosfliolents and the theory, a comparison to experimental results 18 made by oomparing the maximum moments, the phese relationships of maximum moments to the surface wave orest, and comparing the oaloulated and measured total moment time histories. A comparison of the coefficlents obtained by these experiments to other published coeffiolents obtained in different manners, some being steady-flow values, shows that the results hereln are of the right order of magnitude but have considerablo variability.* Further investigation of the problems would olarify the roasons for the scatter of the coefficients.

Using the experimentally determined ooeffioients, the moment distributions on uniform diameter and variable diameter round pilos wers computed and compared to the measured distributions. The computed results are shown to prediot the moment distribution with reasonable accuracy for design purposes.

* Errors occurred In Chapter 28, "Design of Plling" in the Proceedings, First Conference on Coastal Engineoring and are oorrooted in the Appendix of this Chapter. 


\section{EXPERIMENTAL STUDIES OF FORCES ON PILES}

The effeots of size, shape and spaoing of piles were obtained experimentally. Sheltering and mutual interferenoe offects wore found for piles arranged in rows or oolumns. Results are presented in comparative form as moment ratios with respeot to ainglo oylindrioal pile. Center piles in rows of piles all gned parallel to the wave orests showed maximum moments that were higher than those for a single isolated pile. The moment depended upon the relative olearanoes. Moments on piles arranged in columns parallel to the direotion of the wave travel showed a sheltering offeot on the oenter piles in the oolumns with moments $108 \mathrm{~s}$ than those for a single isolated pile.

Momonts on pilos suoh 28 an B - section and a flat plate seotion were larger than those for oylindrioal piles of the same projected area.

\section{THEORE TI CAL CONSIDERA TI ONS}

The dynamic force on an objeot in fluid moving with a seadystate velooity relative to the objeot is given by the expression

where

$$
E=\frac{t}{2} C_{D} \rho u^{2}
$$

$C_{D}=$ cooffioiont of drag.

$\rho$ - fluid density.

$\Lambda=$ projeoted area of objeot perpendicular to the velooity.

$u=$ undisturbed fluid velooity relative to the object.

The ooeffioient of drag must be determined experimentelly. It inoludes the dynamio offocts of friotional drag and of form drag resulting from the disturbance of the fluid in the vioinity of the body.

In steady stato fluid flow the drag ooeficient is related to the flow by the Roynold number given by the expression

$$
\mathbf{R}_{\mathbf{0}} \approx \frac{\mathrm{Du}}{\gamma}
$$

where

$D=$ oharacteristio length of the objeot.

$\gamma=$ kinematio viscosity of the fluid.

When the fluid is in non-steady motion past an object, the aooeleration or deceleration of the fluid in the vioinity of the objeot produces a foree component. Adding this faroe due to the fluid inertia to the friotional foroe, the total force is given by the expression (O'Brien and Yorison, 1950),

$$
F=\frac{1}{z} C_{D} \rho \Delta u^{2}+C_{x} \rho V_{m} \frac{d u}{d t}
$$

where

$$
\begin{aligned}
& c_{y}=\text { coeffiatent of mass, } \\
& V_{m}=\text { volume of the displaced fluid. } \\
& \frac{d u}{d t}=\text { acceleration of the fluid relative to the object. }
\end{aligned}
$$

The coeffioient of mass must be determined experimentally. This total foroe does not include any hydrostatio foroes. The system under consideration is essentially in a balanoed hydrostatio fleld. 


\section{COASTAL ENGINEERING}

A pile, extending rertioally in a fluld in motion due to osolllatory mares, is in a non-uniform flow field with respeot to timo and to the submerged p1le length. Consider a pile at any instant of the. Bquation (3) must be writton in the differential form and intograted orer the pile length in ordor to obtain tho total reoultant foroe on the pilo. In Equation (3) the area $A$ is $D$ dS and the dieplaoed rolume $V_{m}$ is $\left(\pi D^{2} / 4\right)$ dS. Thus, the differential foroe on the pile is given by the expression

$$
d P=\left(\frac{1}{2} C_{D} \rho D u^{2}+C_{x} \rho \frac{\pi D^{2}}{4} \quad \frac{d u}{d t}\right) d s
$$

where

$D=$ pile diamotor.

8 a distanoe above the bottom into Pluid.

Equation (4) may be integrated if $C D, C r$, and $u$, and du/dt are known as funotions of time $(t)$, or the phase angle, and of the position $s$. Taking $s=(d+y+\eta)$ whore $d=$ depth of still water, $y=$ depth below the mean water surfioe to the mean partiole position (measured negatirely downward), and $\eta=$ vortioul partiole displacomont about the mon position, and assuming that the horizontal partiole veloolty is zoro whon $\eta=0$, then the horizontal veloolty and aooeleration of the fluid in wave aotion are given by the expressions (Stokes, 1901),

$$
u=\frac{\pi \text { H }}{T} \frac{\cosh \frac{2 \pi s}{L}}{\sinh \frac{2 \pi d}{L}} \cos \theta
$$

and

$$
\frac{d u}{d t}=\frac{2 \pi^{2} H}{I^{2}} \frac{\cosh \frac{2 \pi s}{L}}{\sinh \frac{2 \pi d}{L}} \sin \theta
$$

where

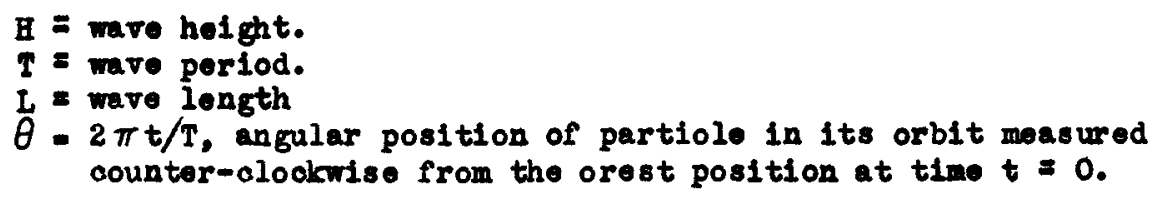

The ooeffloients $C_{D}$ and $C_{Y}$ depend upon the state of the fluid motion with respeot to the objeot motion. Littlo is known about el thor of the cooffiolents in aooelerated systems. As a first approximation they are considered as oonstant with respect to time and position to onable integration of Equation (4). Thus, $C_{D}$ and $C_{M}$ become orerall oooffioients.

This study is based on the total moment about the bottom of the pile, or the total moment contributed by the wave motion abore any level, $S_{i}$, above the bottom. This moment is giren by the expression

$$
u_{1}=\int_{s_{1}}^{s_{s}}\left(s-s_{1}\right) d F
$$




\section{EXPERIMENTAL STUDIES OF FORCES ON PILES}

In order to simplify the calculations of the first fow experiments made, it was assumed that the wave olevation above or bolow mean water level oontributed little to the total moment about the bottoms that is, $\eta$ at the surface was small compared to d. Hence in Equation (7) the ware surface $S_{s}$ is reduoed to $d$ and $S=d+y$. By making the ne0essary substitutions into Equations (4) and (7) and integrating, wo have

$$
\begin{aligned}
F_{i} & =\pi \rho \frac{D H^{2} L}{T^{2}}\left\{ \pm C_{D} k_{1} \cos ^{2} \theta+C_{1} k_{2} \frac{\pi D}{4 H} \sin \theta\right\} \\
u_{1} & =\rho \frac{D H^{2} L^{2}}{T^{2}}\left\{c_{D} k_{3} \cos ^{2} \theta+C_{1} k_{4} \frac{\pi D}{4 H} \sin \theta\right. \\
& \left.-\frac{2 \pi s_{1}}{L}\left[c_{D} \frac{k_{1}}{2} \cos ^{2} \theta+\frac{k_{2}}{2} \frac{\pi D}{4 H} \sin \theta\right]\right\}
\end{aligned}
$$

The line of aotion of the resultant total thrust, $F_{1}$, above the level, $s_{1}$ is given by the expression

$$
\bar{s}=\frac{\mathbf{M}_{1}}{\mathbf{F}_{1}}
$$

where

$$
\begin{aligned}
& k_{1}=\frac{\frac{4 \pi d}{L}-\frac{4 \pi s_{i}}{L}+\sinh \frac{4 \pi d}{L}-\sinh \frac{4 \pi s_{i}}{L}}{16\left(\sinh \frac{2 \pi d}{L}\right)^{2}} \\
& k_{2}=\frac{\sinh \frac{2 \pi d}{L}-\sinh \frac{2 \pi s_{i}}{L}}{\sinh \frac{2 \pi d}{L}}
\end{aligned}
$$

$k_{3}=\frac{\frac{1}{8}\left(\frac{4 \pi d}{L}\right)^{2}-\frac{1}{8}\left(\frac{4 \pi s_{i}}{L}\right)^{2}+\frac{4 \pi d}{L} \sinh \frac{4 \pi d}{L}-\frac{4 \pi s_{i}}{L} \sinh \frac{4 \pi s_{i}}{L}-\cosh \frac{4 \pi d}{L}+\cosh \frac{4 \pi s_{j}}{L}}{64\left(\sinh \frac{2 \pi d}{L}\right)^{2}}$

$$
k_{4}=\frac{\frac{2 \pi d}{L} \sinh \frac{2 \pi d}{L}-\frac{2 \pi s_{i}}{L} \sinh \frac{2 \pi s_{i}}{L}-\cosh \frac{2 \pi d}{L}+\cosh \frac{2 \pi s_{i}}{L}}{2 \sinh \frac{2 \pi d}{L}}
$$

Bquation (9) for the total moment contains sine and cosine terms which are funotions of the angular position, $\theta$. Thus, a phese angle is indicated which depends upon the relative magnitude of the sine and cosine terms. The wave equations (5) and (6) are reforonoed at wave orest at time $t=0$. The phase angle, $\beta$, of the maximum moment in rolationship to the wave crest is determined by differentiating Equation (9) with respoct to $\theta$ and setting the results equal to soros thus,

$$
\beta=\sin ^{-1}\left\{\frac{\pi D C_{1}\left(k_{4}-\frac{2 \pi s_{1}}{L} \frac{k_{2}}{2}\right)}{8 \text { B } c_{D}\left(k_{3}-\frac{2 \pi s_{1}}{L} \frac{k_{1}}{2}\right)}\right\}
$$


The phase angle of Equation (15) shows that the maximum moment usually does not oocur when a wave orest passes a pile. Then the pile is in water which is shallow oompared to the wave length (d/L small), the phase angle approaches soro. When the pile diamoter is small compared to the wave height (D/B small) the phase angle also approaohes zero. The phase anglo approaches 900 for piles in deep water ( $d / L$ largo) or for large piles in small waves (D/ti largo).

Measured moment-time histories on the pile and wave surface-time histories at the pile are used to determine $C_{D}$ and $G$ from Equation ( $\theta$ ). Two variables are inrolved whioh nooessitate selootion, of two times with the oorresponding two moments. The solution is simplified if the seleoted times are zero (orest or trough at the pilo) and the one-quarter or three-quarter wave length time (surface profile at the mean water levol). These times result in $\sin \theta=0$, and $\cos \theta=0$, respeotively. Thus, the soleoted points reduce Equation (9) to two equations, each with but one unknown, $C_{D}$ and $C_{M}$, respeotively.

The moment distribution on a non-uniform pilo, that is a pile whioh oonsists of various lengths of different diametors (Fig. 1) rosults from summation of the moments contributed by each section. The solution of Equation (9) for this system is given by the expression,

$$
\begin{aligned}
y_{n}= & \sum_{j, 1} \rho \frac{D_{j} H^{2} L^{2}}{T^{2}}\left\{c_{D} k_{z_{1}} \cos ^{2} \theta+\frac{\pi D_{j}}{4 B} C_{M} k_{L_{i}} \sin \theta-\frac{2 \pi s_{n}}{L}\right. \\
& {\left.\left[c_{D} \frac{k_{1_{1}}}{2} \cos ^{2} \theta+\frac{\pi D_{j}}{4 H} C_{M} \frac{k_{1}}{2} \sin \theta\right]\right\} }
\end{aligned}
$$

whore

$$
\begin{aligned}
& s_{n}=s_{2}, s_{3}, s_{4}, \cdots s_{11} \text {, the eleration at which the total moment } \\
& \text { is caloulatod. } \\
& D_{j}=D_{1}, D_{2}, \cdots-D_{5} \text {, diameter of pile of various seotions } \\
& k_{1_{1}} \text { oto. }-k_{1_{1}}, k_{1_{2}},-k_{1_{n}}, k_{2_{1}}, k_{2_{2}}-k_{2_{n}} \text { the olevation above the } \\
& \text { bottom is boing summed. }
\end{aligned}
$$

The conditions imposed upon Equation (16) in order to perform the sumation rosulting of fect on Equations (11) to (14) are summarized for the conditions illus trated in Figure 1 as follows:

$$
\text { 1. If } \begin{array}{rlrl}
j & =1 & \text { then } 1 & =2,3 \\
j & =2 & 1 & =4,5 \\
j & =3 & 1 & =6,7 \\
j & =5 & 1 & =8,9 \\
j & =5 & 1 & =10,11
\end{array}
$$

2. For any $n=2, \ldots, 11$, the sumetion is carried out for suocessive values of $j$ and the corresponding values of $i$ until $i=n$. (See Fig. 1) 
3. The expressions for $k_{1}, k_{2_{1}}, k_{3_{1}}$, $k_{1 i}$ are the same as $k_{1}, k_{2}, k_{3}, k_{4}$ (Equations il to 14) whore $d$ in the numorator is ohanged to $S_{1-1}$. For examplo, Equation (11) beoomes

$$
k_{1_{1}}=\frac{\frac{4 \pi s_{1-1}}{L}-\frac{4 \pi s_{1}}{L}+\sinh \frac{2 \pi s_{1-1}}{L}-\sinh \frac{4 \pi s_{1}}{L}}{16\left(\sinh \frac{2 \pi d}{L}\right)^{2}}
$$

The orloulation of moments on piles in shallow water must include the effoct of the variation of the lever arm between the orest and trough of the wave. The oquation for the total moment about any lorel $s_{i}$ is the same as Equation (9) where the expression of $k_{1}$, $k_{2}, k_{3}$, and $k_{4}$ (Equations $11,12,13$ and 14) have $S_{s}$ in the numerator instead of $d$. For example Equation (II) bocomes

$$
\mathrm{k}_{1}=\frac{\frac{4 \pi \mathrm{S}_{8}}{\mathrm{~L}}-\frac{4 \pi \mathrm{S}_{2}}{\mathrm{~L}}+\sinh \frac{4 \pi \mathrm{S}_{3}}{\mathrm{~L}}-\sinh \frac{4 \pi \mathrm{S}_{1}}{\mathrm{~L}}}{16\left(\sinh \frac{2 \pi \mathrm{d}}{\mathrm{L}}\right)^{2}}
$$

where $S_{B}$ is the elevation to the water surface above the bottomo

The oaloulation of an expleoit expression for the phase anglo, similar to Equation (15)

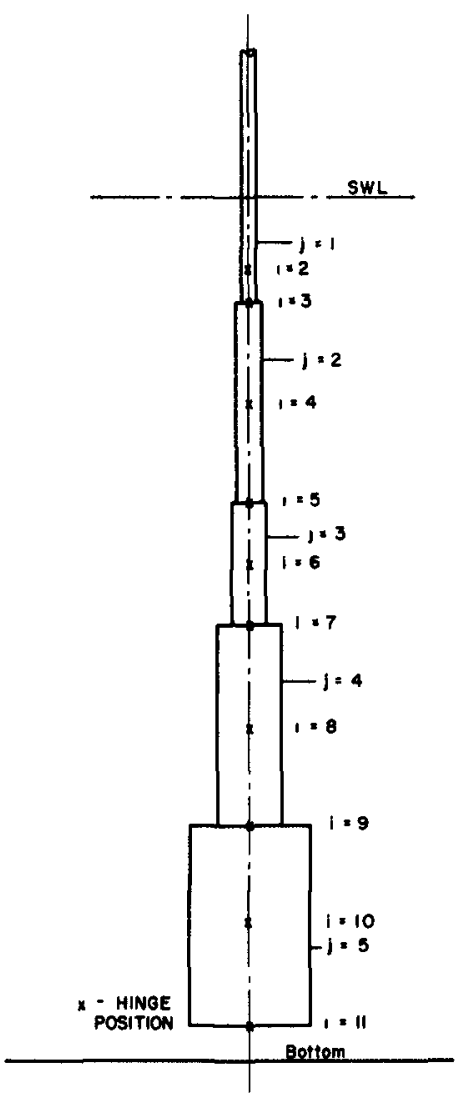

FIg. 1 when oonsidering the ohange in surface elevation is impossible so that it booomes necessary to plot a graph of equations or use approximato methods to obtain the phase angle of the total moment with respect to the ware orest (See Fig. 10).

In order to evaluate the total moment exorted on a pile subjeoted to a known wave condition, the ooeffioients and $C_{y}$ must be known. Keasurements of the moment time history of piles subjeot to known wave oonditions onablo evaluation of $C_{D}$ and $C_{y}$. The established ooefficients then oan be used to prodiot moments on piling for any pilo and imposed ware conditions subject to the limitations and approximations of the analysis which leads to Equations (8), (8) and (15).

The drag ooefficient, $C_{D}$, in Equations (8), (9) and (15) is oom parablo in significanoo to tho stoudy state drag ooeffioiont of Equation (1). Thus, comparisons may bo made between the drag oceffloients which result from moasurment on piling subjeot to the poriodic motion of wave action and those reported in the literature for the same geometrical systems in a stoady tate fluid stream. The stoady tato drag cooffi of ents are funotions of the Reynolds number, Equation (2), in addition to the 


\section{COASTAL ENGINEERING}

geometrioal shape. In periodio motion the Reynolds No. varies from zero to a maximum. The maximum influenes of the motion of a wave past pile oocurs near the surface in the reglons of the highest velooity. Henoe, the orest partiole velooity is assunod to be most nearly representative of the relooity to be used in the Reynolds number. Inis results from Equation (5) with $8=d$ and $\theta=0$.

\section{BXPERIMGNTAL INVES TIGATIOUS ON YODEL PILAS}

Ixperiment were designed to measure the moment history on piles of constant and variable dianoter about hinge points in the piles when subjected to wave aotion. The wave shape was measured simultaneously to determine the helght, veloolty, and period of the wave at the pile. The wave length is related to the velooity and period as follows:

$$
\mathbf{L}=\mathbf{C} \mathbf{T}
$$

From the mosuremente of the variables, the ooeffiolents $C_{p}$ and $C_{M}$ wore obtained from Bquation (9). Onoe having dotermined the ooeffiolent, then evaluation of the moments was possible for a given pile subjeoted to knom ware action.

Experiments were conducted in the wave ohannel at the University of Cal1fornia (Yor18on, 1950a, 1950b, 19500.

Tests on single olroular pilest Tomonts wore wesured on single piles hinged at the bottom as woll as at various elerations, (F1g. 2). In one instanos a 1 Inoh diametor pile wa hinged only at the botton and subjeoted to a large range of wave conditions. In another series of tests, piles of $1 / 2,1$ and 2 inohes in diameter wore subjected to three different were conditions, and the moments were obtained at hinge points located at various eleretions to obtain moment distributions. A summary of test conditions 18 presented in Table 1 , and a summary of the test results is given in Table 2 .

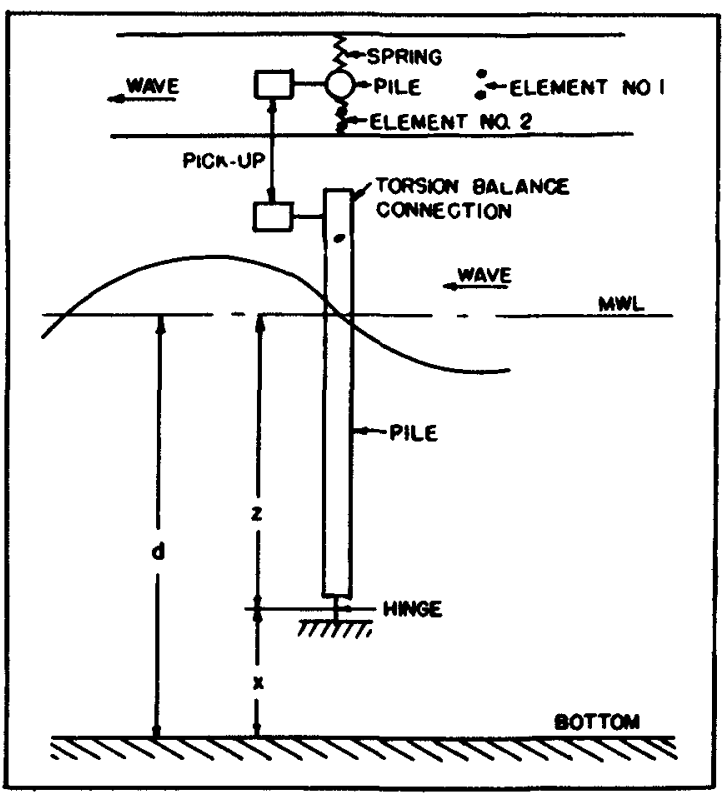

$\mathbf{F}$ g. 2 


\section{EXPERIMENTAL STUDIES OF FORCES ON PILES}

Table 1.

Summary of test conditions on oircular piles

\begin{tabular}{|c|c|c|c|c|c|c|}
\hline $\begin{array}{c}\text { Pile } \\
\text { No. }\end{array}$ & $\begin{array}{c}\text { D } \\
\text { inohos }\end{array}$ & $\begin{array}{l}d \\
\text { ft. }\end{array}$ & \multicolumn{3}{|c|}{ Wave Chareoteristios } & Remarks \\
\hline 1 & 1 & 2 & ( & variable & ) & $\begin{array}{l}\text { Moments moasured only at the } \\
\text { bottom }\end{array}$ \\
\hline 2 & $\frac{1}{2}$ & 1.96 & 0.98 & 0.184 & 4.91 & Moments mossured at 7 elevations \\
\hline 3 & 1 & 1.96 & 0.98 & 0.179 & 4.98 & Momonts moasured at 6 elevations \\
\hline 4 & 2 & 1.96 & 0.98 & 0.186 & 4.96 & Moments mosured at 6 olevations \\
\hline
\end{tabular}

Tablo 2.

Summary of tost results on oiroular piles

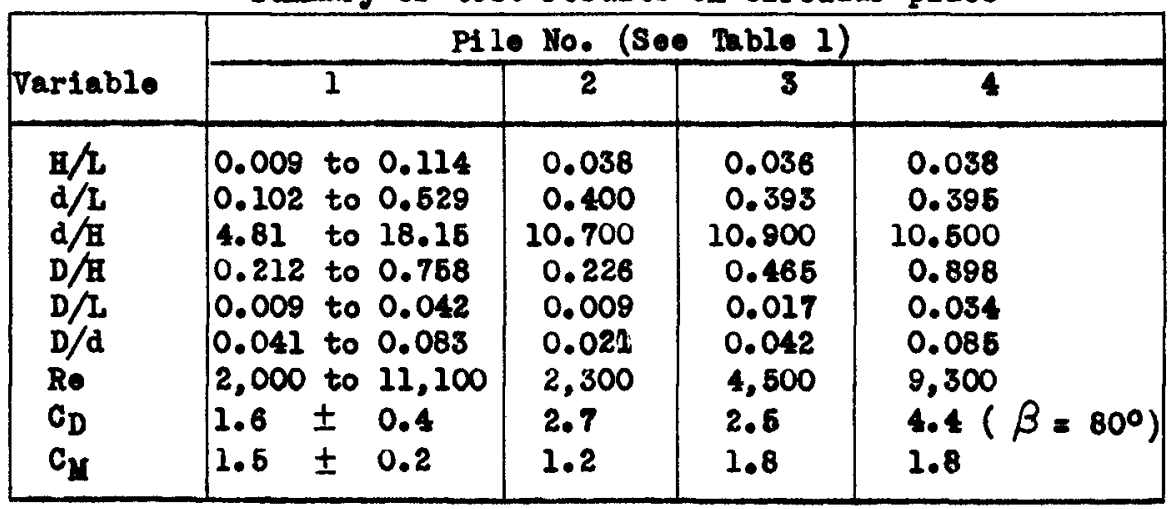

Somo results wore obtalnod for a pile placed in breaking wares. The doparture of aotual oonditions from the assunod oonditions as stated in the development of Equation (9) was too great to justify use of this -quation in the interprotation of rosults in broakers. The results showed maximum moments produoed by a breaker or inoipient breaker greatly in oxoess of the forces oorresponding to the orbital motion desoribed by Equation (9)

The ooeffioients as dotermined for any one wave oondition were used with Equation (9) to oompute the ocmplete moment history over the oyole erca one ware orest to the next. $\Lambda$ typioal ocmparison is shown in Fig. 3 .

Momont distribution oomparisons wore made for piles 2, 3, and 4 (Tablo 1). Bquation (9), with values of $C_{D}$ and $C_{y}$ from the moasured moment history at the botton of the pile, was used to oompute the moment ratio as anotion of dopth for ocmparis on with the experimental ratio. Results are shown in Fig. 4. 
COASTAL ENGINEERING

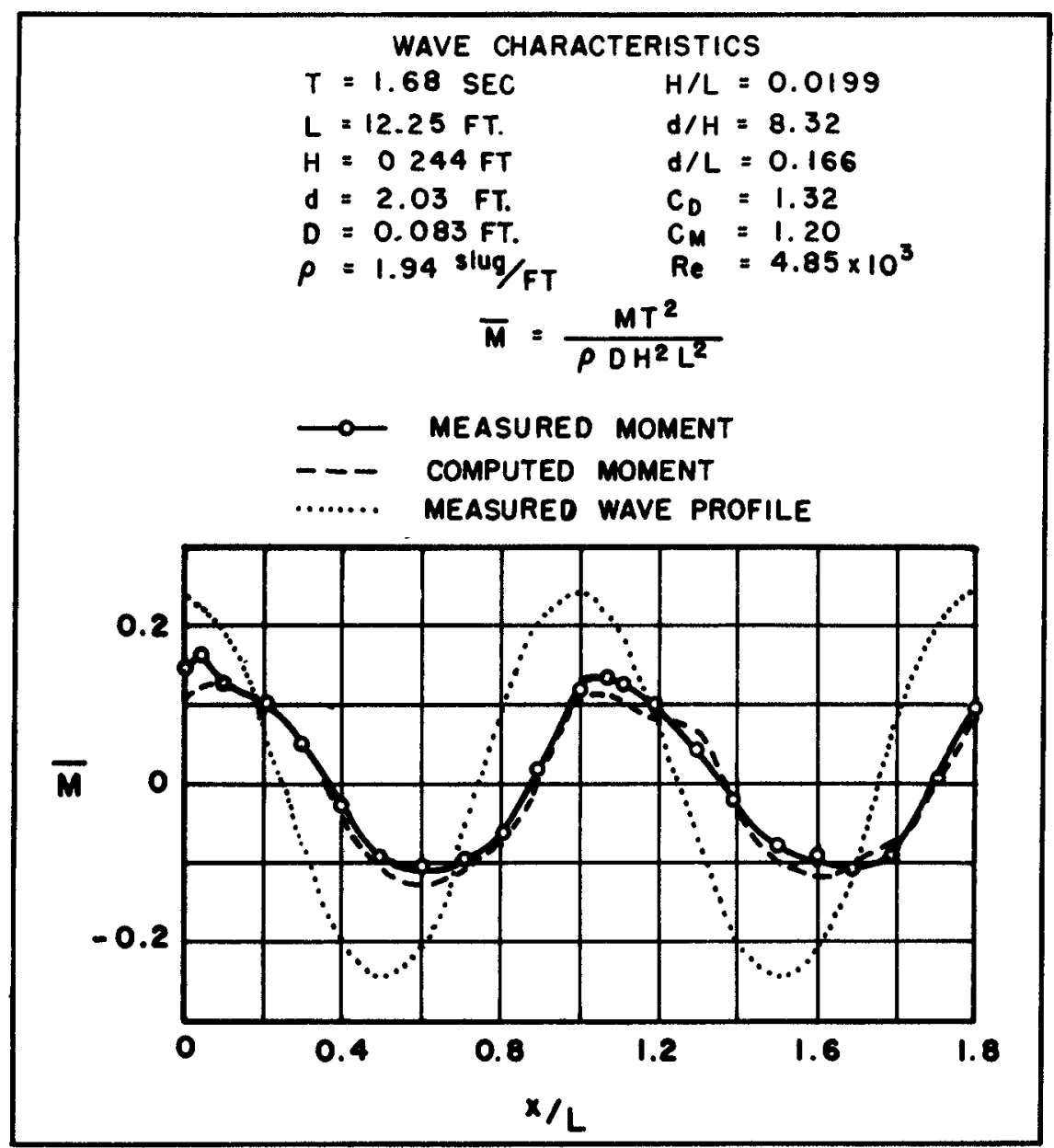

Fig. 3. Total moment about the bottom of a single circular pile. 


\section{EXPERIMENTAL STUDIES OF FORCES ON PILES}

In Fig. \& certain fentures should be noted. The coefficients $C_{M}$ and $C_{D}$ were ovaluated from the moment history at values of $0, \pi / 2$, $\pi,(3 / 2) \pi$ of the angular partiole position with respeot to the wave orest. Thus, the ocmputed maximum moment may be different from the measured maximum moment for these oonditions where the phase angle between the wave orest and maximum moment is different from zero. The computed curves, Fig. 3, show this differenoe. That is, at $y / d=1.00$ (bottom), the maximum measured moment and the maximum computed moment do not coincide. Howerer, the shape of the moment distribution as a function of depth, using the average values of $C_{D}$ and $C_{M}$ from the measured moment at the bottom to oompute the moment at any depth, follows the trend of the measured moment distribution.

A further comparison may be made of the effect of pile diameter on the roment distribution by reduoing the moment distribution to ratio in terms of the maximum moments. Results are shown in $F_{1 \mathrm{~g}} .5$ for one wave condition. The oomputed moment ratio and the experimental moment ratio are in agreement within the limits of experimental orror. The pile diameter does not have any influence on the moment distribution. Hence, attention can be concentrated on obtaining moments about one hingo point to establish the necessary criteria to enable prediction of the moments on a pile due to wave action.

Bithin the accuracy of values of $C_{D}$ and $C M$, the resultant foroe as a function of time or wave position relative to the pile may be obtained from Equation (8). The action line of the total resultant foroe is obtained from

$$
\bar{s}=\frac{\mathrm{Md}}{\mathrm{F}}
$$

where $\bar{S}$ is the location of the action line above the bottom and $M_{d}$ is the moment about a hinge point at the bottom. The resultant force on a pile above a hinge point at any position in the pile may be obtained in a similar manner except for the seotion of the pile near the water surface.

In these tests forces were not computed, since attention was concentrated on obtaining reliable values of $C_{D}$ and $C_{M}$ from moment
histories.

Tests on a variable diameter pile: The total moments exerted by waves on a pile which had varied steps of diameters was determined by a model study. The dimensions of the model are shown in Fig. 6. No attempt was made to deterraine the coefficients, $C_{D}$ and $C_{M}$ from the results on the stepped pile.

Three conditions of the stepped pile were investigated with respect to the coefficients $C_{D}$ and $C_{M}$ as determined in the disoussions above for single cylindrical piles. the moment contributed for each section of the pile was computed from Equation (16) using $C_{D}=1.63$, $c_{y}=1.51$, and the experimentally measured phase angle, $\beta_{d}$, of the total moment about the bottom. Comparison of the monent distribution in the form of the ratio of the moment resulting from the wave action 


\section{COASTAL ENGINEERING}

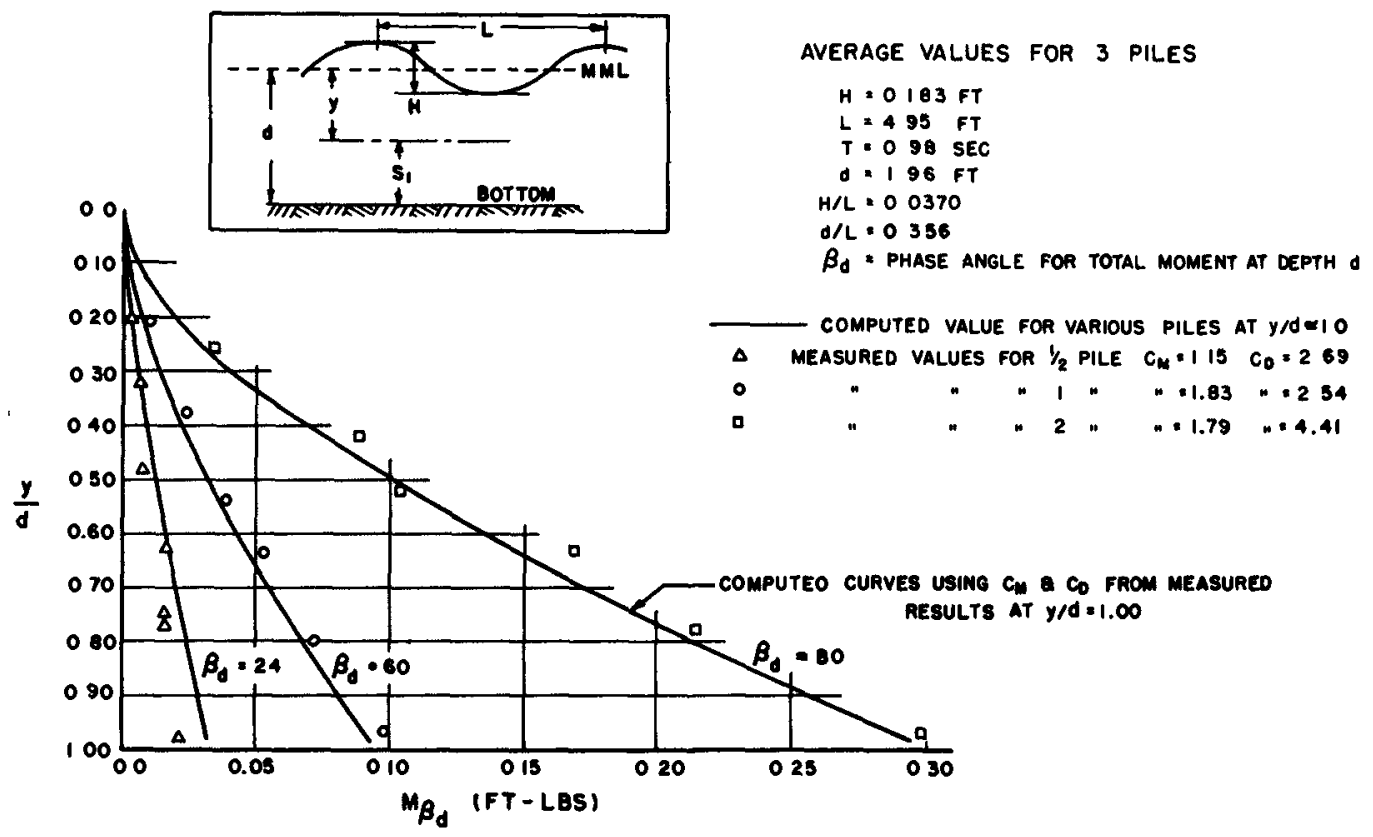

Fig. 4. Moment distribution on uniform pilo Laboratory rosults.

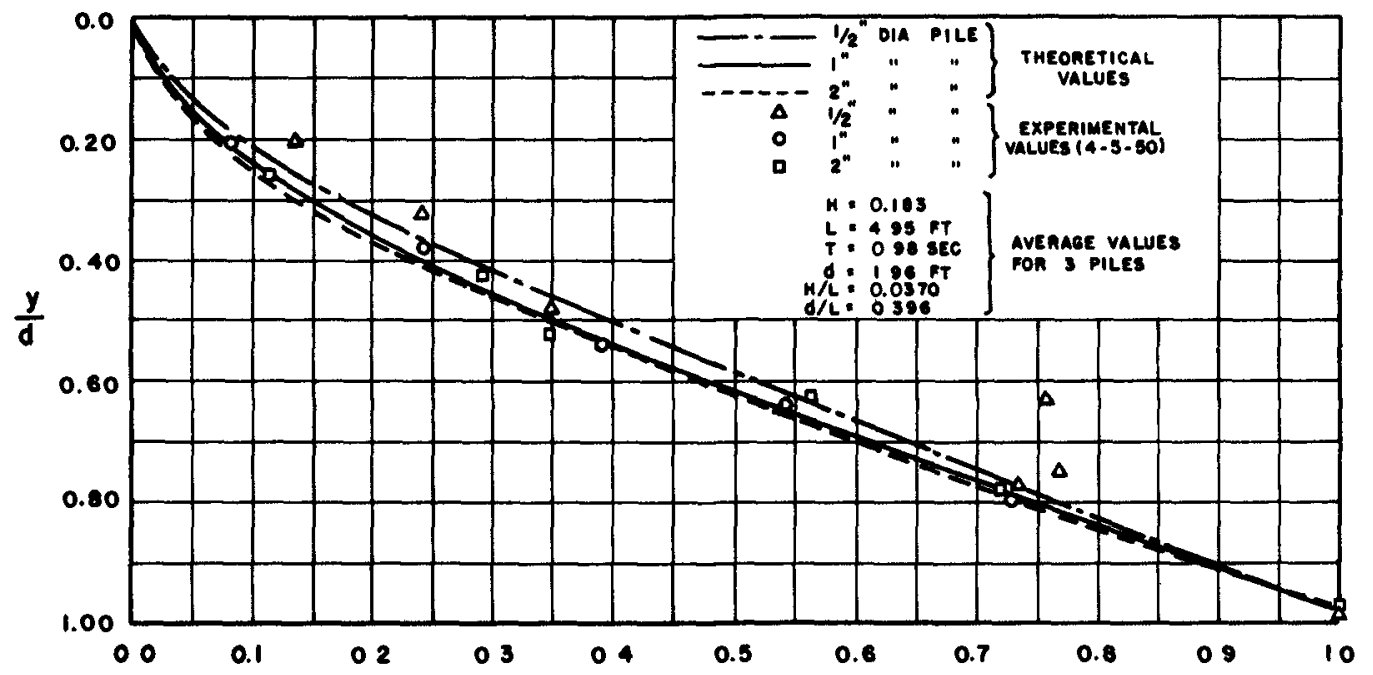

$M / M_{\text {max }}$

Fig. 5. Dimensionless moment distribution of uniform pilo. 


\section{EXPERIMENTAL STUDIES OF FORCES ON PILES}
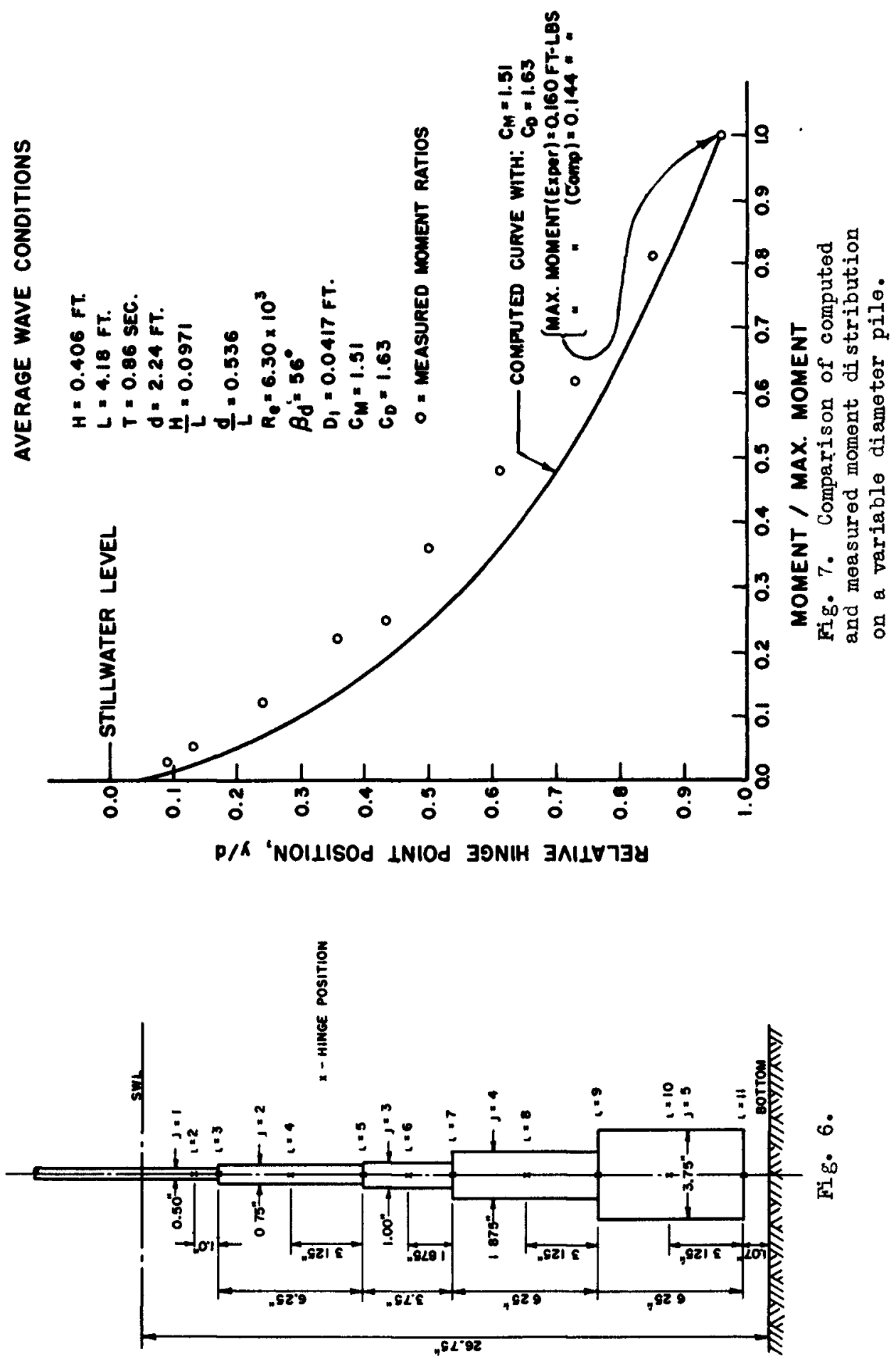


\section{COASTAL ENGINEERING}

above any solected point to the maximum monent about the hinge point at the bottom is shown in Fig. 7 .

Tests on piles of various cross-sectional shapes, The moment history of piles with varlous cross-seotional shapes was determined in the laboratory with the equipment shown in Fig. 1. The pile orossesections were ciroular, flat plates and H - seotions with one-inch projected width in the normal dimension as detailed in Fig. 8. Results were interpreted as ratios of the maximum monent for any given shape to the maximum moment for the ciroular shape (Table 4). The B - section was oriented in thres different directions as shown in the table. All piles were subjected to the same wave conditions as indicated in Table 3 .

Table 3

Wave conditions in tests on oircular piles, flat plates and $H$ - sections.

\begin{tabular}{|l|l|l|l|}
\hline Parameter & Ware 1 & Ware 2 & Wave 3 \\
\hline H, ft. & 0.681 & 0.342 & 0.454 \\
L, ft. & 7.54 & 3.87 & 5.39 \\
T, sec. & 1.27 & 0.88 & 1.09 \\
d, ft. & 1.55 & 1.50 & 0.83 \\
H/L & 0.0903 & 0.0884 & 0.0843 \\
d/L & 0.206 & 0.388 & 0.154 \\
\hline
\end{tabular}

Table 4

Effect of pile shape on maximum moment.

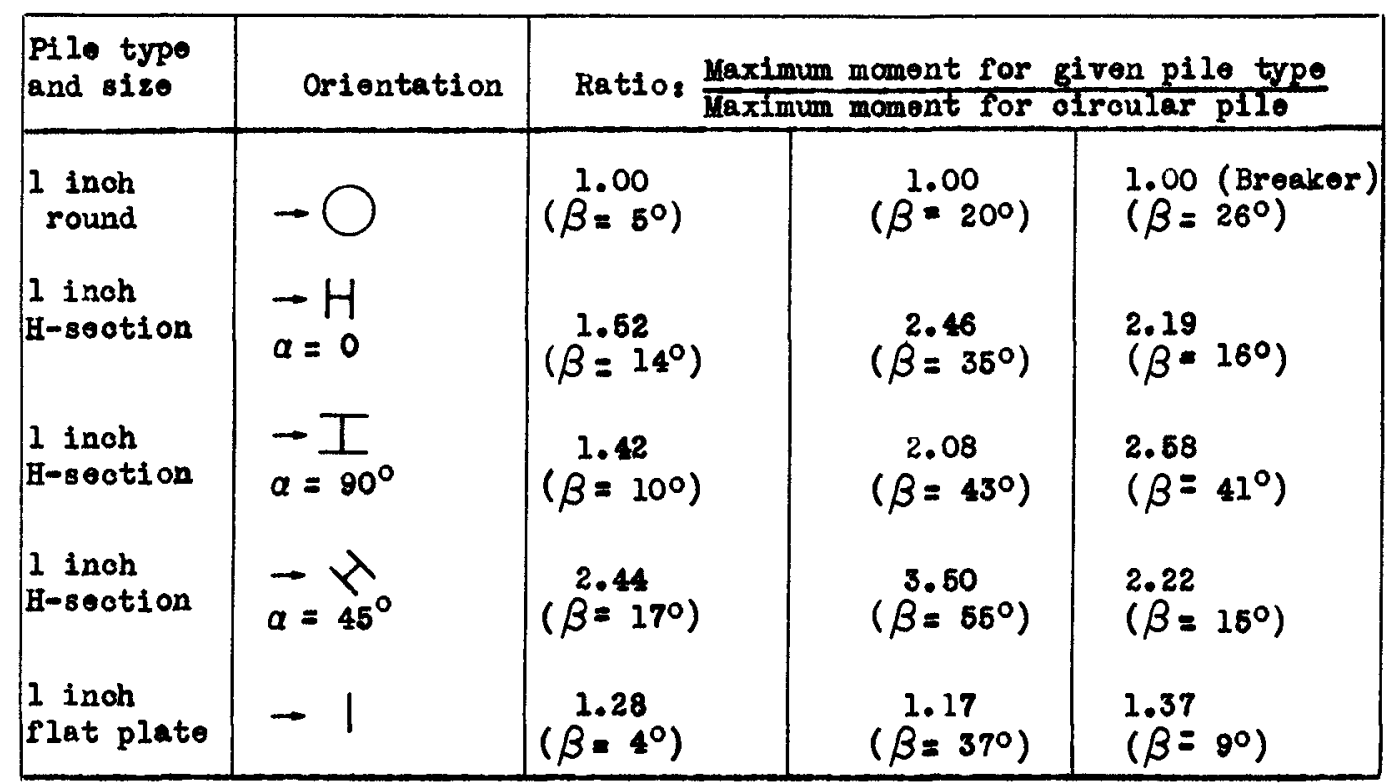




\section{EXPERIMENTAL STUDIES OF FORCES ON PILES}
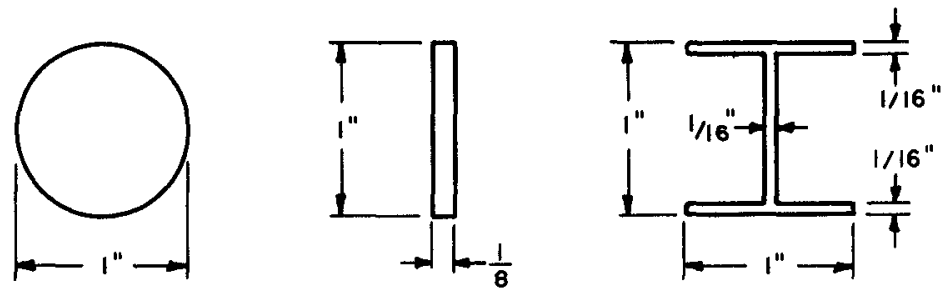

DIMENSIONS OF MODEL PILES

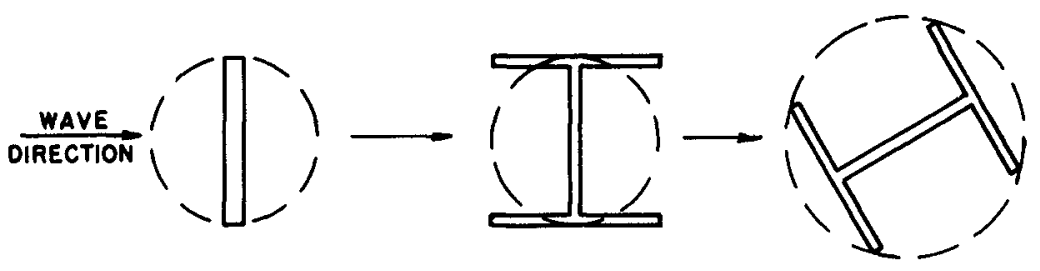

EQUIVALENT CYLINDER

SHOWN BY DASHED CIRCLE

Fig. 8. Cross soctions of piles.

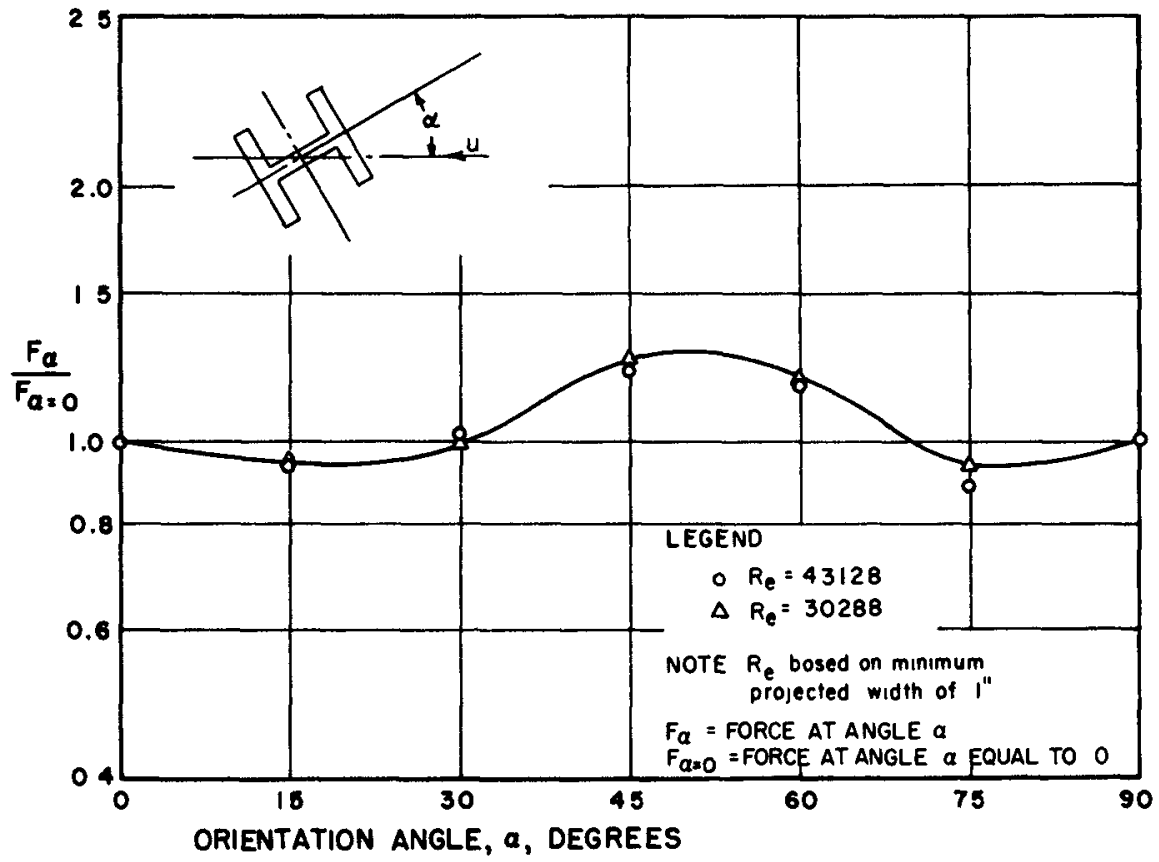

Fig. 9. Moasurod H-soction drag forco in stoady, uniform flow as a function of oriontation. 


\section{COASTAL ENGINEERING}

The force on the $\mathrm{H}$ - section wa determined in a wind tunnel under steady-state oondition as a function of orientation of the aeotion. The maximum foroe resulted at approximately the $45^{\circ}$ orientation as is show in Fig. 9. Thus the pile results for that orientation were considered as folng the maximum moment (primarily because this orientation gave the greatest projected area); consequently, under wave action the orientation of the $\mathrm{H}-\mathrm{section}$ was not varied over angles other than the $45^{\circ}$ wth respect to the dirootion of wave travel.

One comparison oan be made using the H-seotion results of the steady-state force ratio and the maximan moment ratio in the ware aotion. Ratios of the maximum moment of the H-section oriented with values of $\alpha$ other than sero to the maximum mament with $\alpha=0$ may be compared to the corresponding steady-state force ratios. (Note that the monent arm 18 constant in the comparison, henoe monents should be in the same ratio as foroes assuming the foroe distribution is similar and not a function of orientation.)

This comparison is shown in Table 5.

Table 5

Effeot of orientation on foroes on B-section in steady flow and in os ofllatory flow.

\begin{tabular}{|c|c|c|c|}
\hline \multirow{3}{*}{$\begin{array}{c}\text { Ware } \\
\text { Stoopness }\end{array}$} & \multicolumn{3}{|c|}{ Orientation of pilo } \\
\hline & $\begin{array}{l}-H \\
a=0\end{array}$ & $\rightarrow={ }_{a}=0^{\circ}$ & $\begin{array}{l}\rightarrow \lambda \\
a=46^{\circ}\end{array}$ \\
\hline & Ratio: & \multicolumn{2}{|c|}{$\frac{\text { Foroe (or Moment) at orientation shown }}{\text { Force (or Moment) at a. }}$} \\
\hline 0.0903 & 1.00 & 0.93 & 2.61 \\
\hline 0.0884 & 1.00 & 0.85 & 1.42 \\
\hline $\begin{array}{l}0.0843 \\
\text { (Broaker) }\end{array}$ & 1.00 & 1.17 & 1.02 \\
\hline $\begin{array}{l}\text { Steady } \\
\text { Flor }\end{array}$ & 1.00 & 1.00 & 1.26 \\
\hline
\end{tabular}

Differences between force ratios in steady state and in oscillatory flow are noted in some cases which are greater than any experimental error. Thus, the steady-state drag forces (henoe steady-state drag coefflolents) are not the complete criteria by whioh to evaluate moments of seotions which differ from the oircular section. IhIs comparison would indicate the presence of the inertia force component, a fect which is oonfirmed by the differences in phase angles 11 sted in Thble 4. 


\section{EXPERIMENTAL STUDIES OF FORCES ON PILES}

The plots shown in Fig. 10 are computed, and meesured momenttime histories of a ciroular, an H-section and a flat plate pilo in shallow water where the effeot of the variable lever arm hes been oonsidered by using $S_{S}$ instead of $d$ in Bquations 11, 12, 13 and 14. The ooefficlents of drag and mass computed from the measured ourve are given in

Table 6 along with the wave aharacteristios.

Table 6

Coefficients of drag and mass for shallow wator waves

\begin{tabular}{|c|c|c|c|}
\hline \multirow[b]{2}{*}{ Variable } & \multicolumn{3}{|c|}{ Pile type } \\
\hline & $\begin{array}{c}1 \text { inch } \\
\text { olroular }\end{array}$ & $\begin{array}{c}1 \text { inch } \\
\text { H-seotion }\end{array}$ & $\begin{array}{l}1 \text { inoh } \\
\text { rlat plate }\end{array}$ \\
\hline H, feet & 0.613 & 0.600 & 0.706 \\
\hline I. foot & 7.76 & 7.36 & 8.00 \\
\hline T, 8e0. & 1.25 & 1.27 & 1.27 \\
\hline d, feet & 1.50 & 1.46 & 1.45 \\
\hline $\mathbf{I} / \mathbf{L}$ & 0.079 & 0.082 & 0.088 \\
\hline$d / L$ & 0.193 & 0.198 & 0.181 \\
\hline$\beta$, de grees & 6 & 14 & 0 \\
\hline $\mathbf{R}_{\boldsymbol{e}}$ & 15,000 & 15,000 & $15, \infty 00$ \\
\hline$C_{D}$ & 1.78 & 2.44 & 1.20 \\
\hline $\mathrm{c}_{\mathbf{M}}$ & 0.44 & 1.92 & 0.42 \\
\hline
\end{tabular}

One feature of the interpretation of the equations from whioh the ooeffiolents of mass and drag wore ocmputed is evident in the results show in Table 6. When the phase angle is small, the mas ooeffloient is evaluated from moments wioh are near the point of zero moment. Small experimental or rors become $81 \mathrm{gnifloant}$ and roduce the roliability of the value of the mass coefficient. The mass coeffioients for the oiroular pile and the flat plete pile are small as canpared to thoee reported in Table 2. These low coeffioients are not representative. 


\section{COASTAL ENGINEERING}
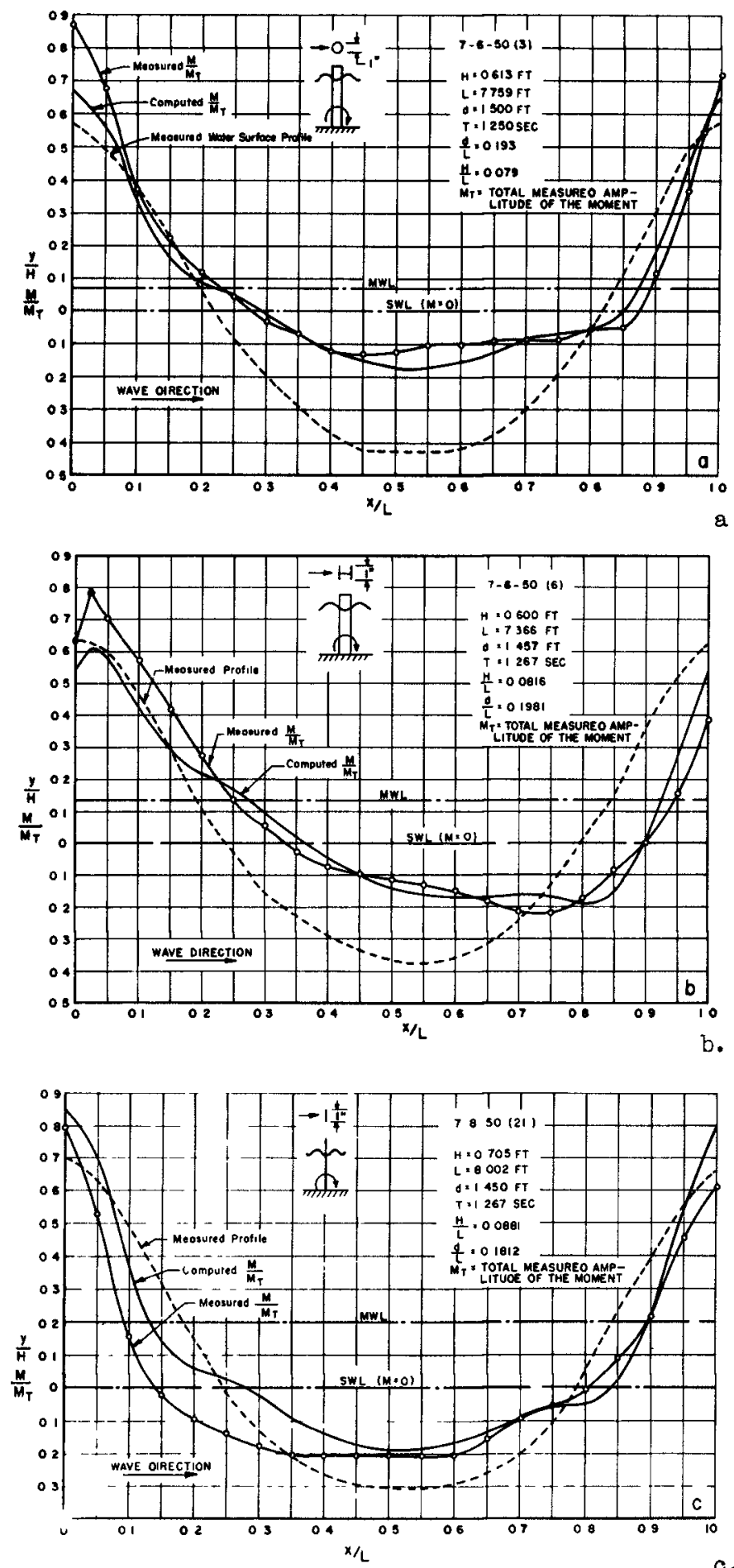

Fig. 10. Computed and measured time history ${ }^{\circ}$ of total moment on circular, H-section, and flat plate piling. 


\section{EXPERIMENTAL STUDIES OF FORCES ON PILES}

Effeot of mutual interferenoe of piles, The one-inoh oiroular and flat plate piles were arranged In rows parallel to the wave direotion and in columns perpendioular to the wave direotion (seo Fig.11). Three piles were used in each oase with moment measurements made on the center pile (FIg. 12). Spaoings between the piles were $7 D, D$ and $1 \frac{1}{2} D$, where $D$ is the pile diameter. Resulte are shown in Table 7. The ratio of the maximum moment on the center pile of the oolumn or ror to the maximum moment on a single pile shows the results of interferenoe effeots. The wave oonditions used were the same as 11 sted in Table 3.

\section{Tablo 7}

Effect of mutual interferenoe of piling

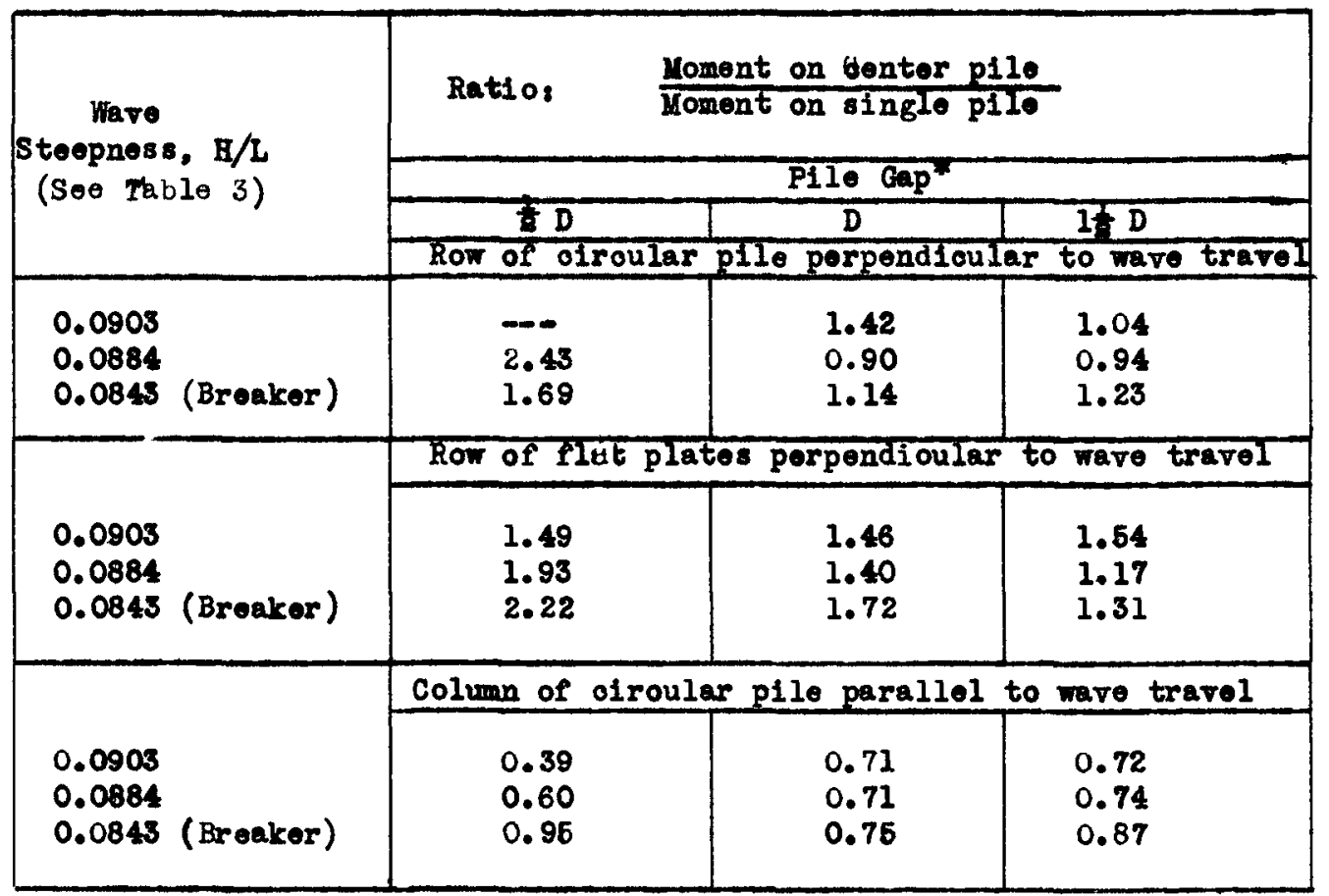

* $D=1$ inoh for all pilos.

The results show that, at spaolngs of less than $1 \frac{1}{8} D$ in the row arrangement, interforence offeots are notioeable. Higher moments are experionoed by the oenter pile as contrasted to single pile. The blooking offoot of adjaoent piles inoreases the foroe and resulting moment on an individual pile. The blooking offeot docreases as the spacing betweon piles inareases. For the limited range of the tests, the blooking offeot is oonoluded to be negligible for spacings of $1 \frac{1}{2} D$ or greater.

Results from the piling arranged in oolumes show a sheltering of feot, (Table 7) in that moments were less than those represented by a 
single pile. The maximum saoing at whioh the sheltering effect is negligible was not reached in these tests.

Foroes on oross members: The measurement of the horizontel force on oross-menbers was made on a force balance apparatus. The oross-member wes mounted on a rod whioh was piroted near its oenter and restrained by calibrated springs at one end (Fig. 13). The submerged part of the rod was shielded from the wave aotion so that a tare test, without the arosa-member attached, showed only about one-peroent defleotion. The foroe and the wave oharaoteristics were reoorded in the same manner as in the oase of the single piles. Three lengthe ( 2 t, 5 and 10 inches) of oross-members were used 80 that the ond effoots oould be determined.

The measurement of the vertical foroe on erossmembers was made direotly by a calibrated spring system. The oross-member was plaoed at the end of a vortical rod that was attached to springe (Fig. 14). The submerged part of the rod was shielded and held in guides near the crossnomber. A tare test showed less than ono-peroent defleotion. The wave oharacteristios were measured 1 s leet in front and lit feet bohind the oross-member with a referenoe mossurement of the wave orest being made direotly above the crossmember. The foroe and wave charaoteristios were recorded simultaneously on the same oseillograph record. The same wave conditions were reproduoed as those used for the measurement of the horizontal foroes on the orosemembers. In both the tosts of the horizontal and of the vertical foroes, the same wave oonditions were used for the horisontal and inolined nombers at the $1 / 3$ and $8 / 8$ positions of water depth.

The horizontal foroe per unit length on a cross-momber (mbles 8 and 9) indionted that the orientation of the cross-member is not oritioal for model studies. The test showed also that the ond effeots are not appreciable. The vertioal foroe per unit length on a orossmember (Table 10) Indioated scme effeots due to orientation. The magnitudes of the foroes wore about half those for the horizontal direotion.

\section{FIELD PILE TESTS}

The model teste, as desoribed above, ylelded a considerable amount of information on the moments and foroes on piles subjected to a wide range of wave oonditions and depths of lmersion. The limited size of the model system introduoes a possible scale offeot in the direot applieation of the model results to prediot prototype behavior. Thus, prototype tests wore made in an attempt to oorrelate model and prototype behavior to substantiate the analysis and results from the model tests (Snodgrass, Rice, and Hall, 1951).

The field tests were oonduoted near shore at Monterey, California, with a oylindrieal pilo of 3 it inoh outaide diamotor. The pile was hinged at the bottom at approximately sand level. Restraining bars at the top of the pile were arranged with train gage elements oonneoted to reoording equipment. The strain reoords yielded the foroe-time history of the pile under the action of the inoident raves. Calibrations of the strain reoording equipment were made both in the laboratory and in the fiold. 


\section{EXPERIMENTAL STUDIES OF FORCES ON PILES}

$$
\begin{aligned}
& \text { (0 VARIEO FROM } \frac{1}{2} \text { "TO }\left(\frac{1{ }^{\prime \prime}}{2}\right) \\
& \left(0=I^{\prime \prime}\right)
\end{aligned}
$$

DIRECTION OF WAVE TRAVEL

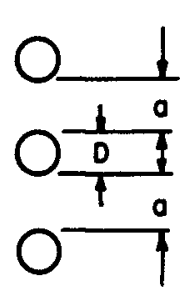

\section{a. ROW OF ROUND PILING}

(PERPENDICULAR TO WAVE TRAVEL)
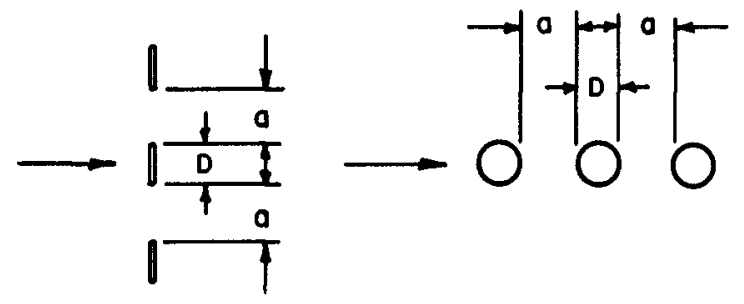

Fig. 11. Arrangement of piling for tests on mutual inter cerence. b. ROW OF FLAT PLATES c. COLUMN OF ROUNO PILING

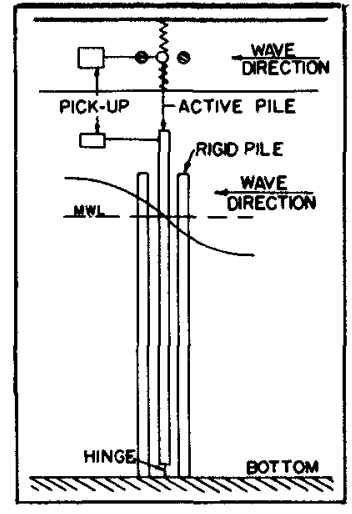

Fig. 12

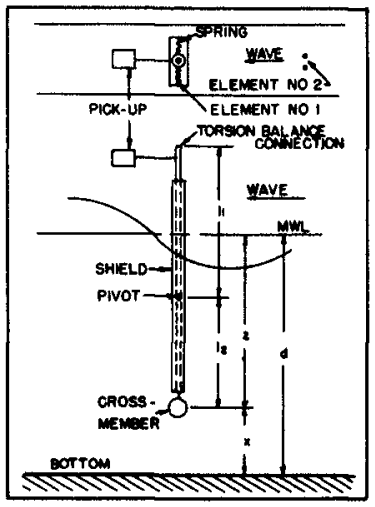

Fig, 13.

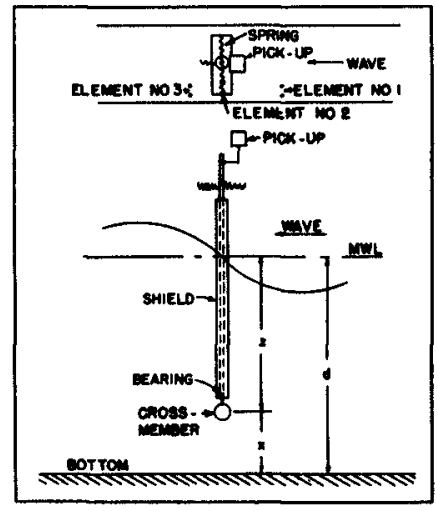

15i. 14. 
COASTAL ENGINEERING

H.

ง๋

รั

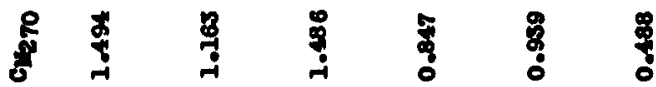

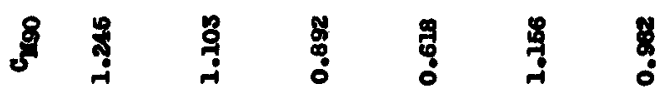

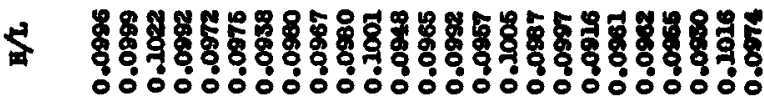

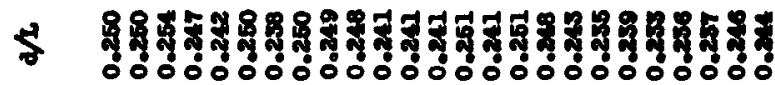

จำ

范 8

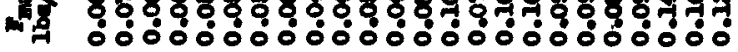

M.

4

- $8888 \%$

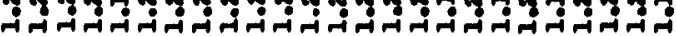

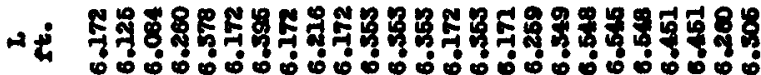

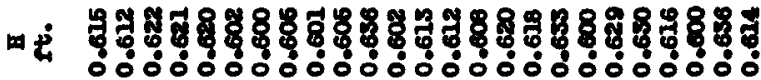

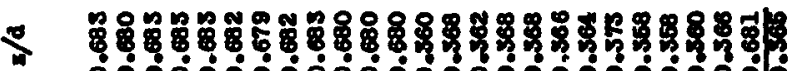

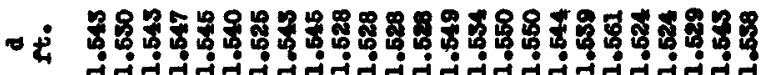

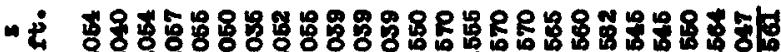
न

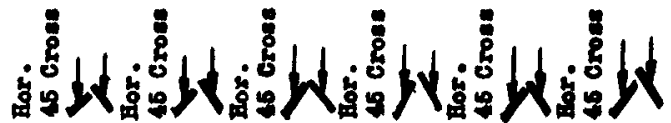

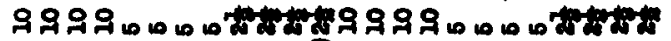

\% 3E

$\$ 0 \%$

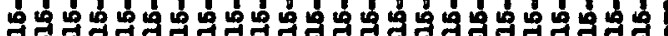

जิ 


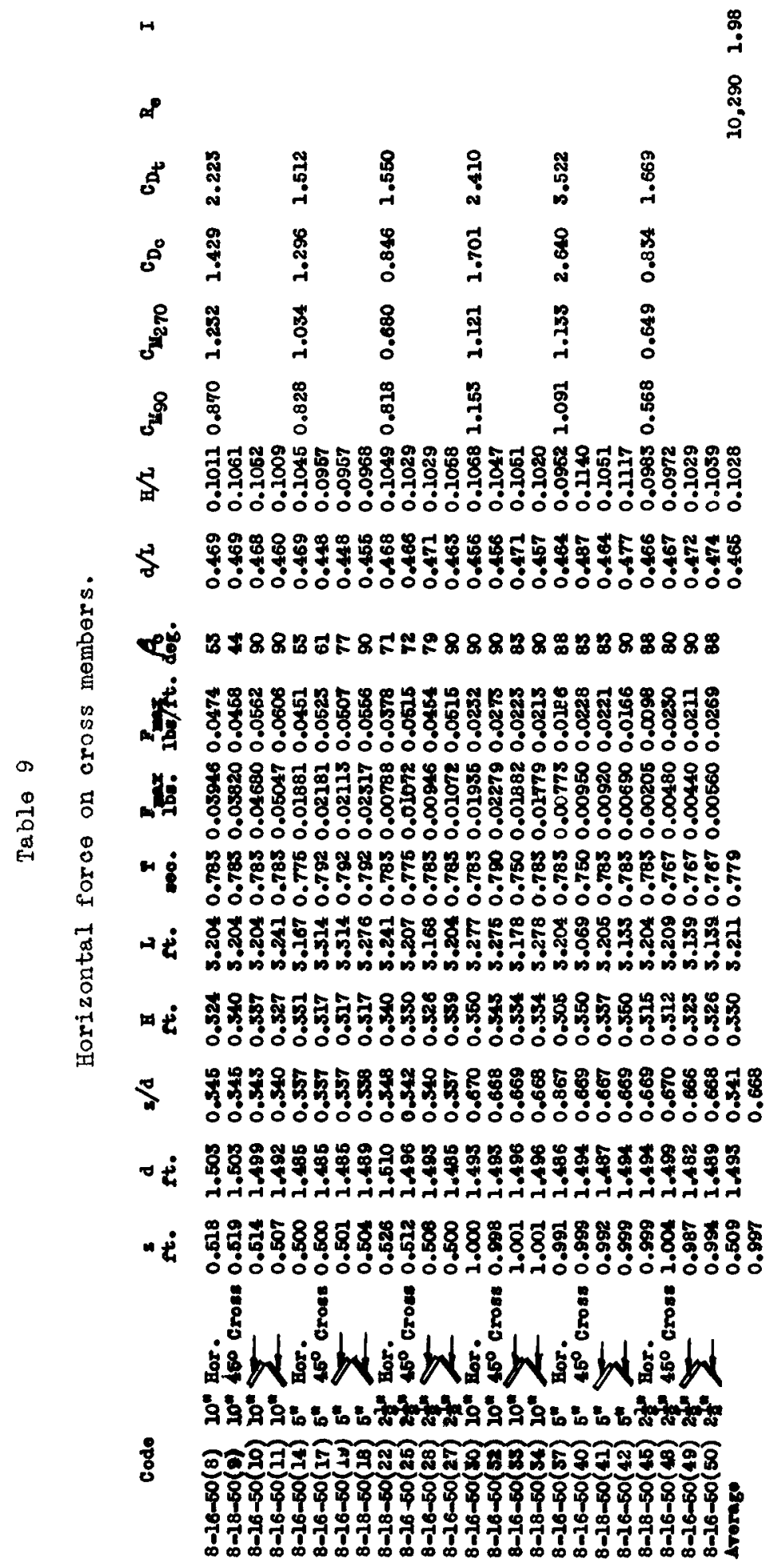


COASTAL ENGINEERING

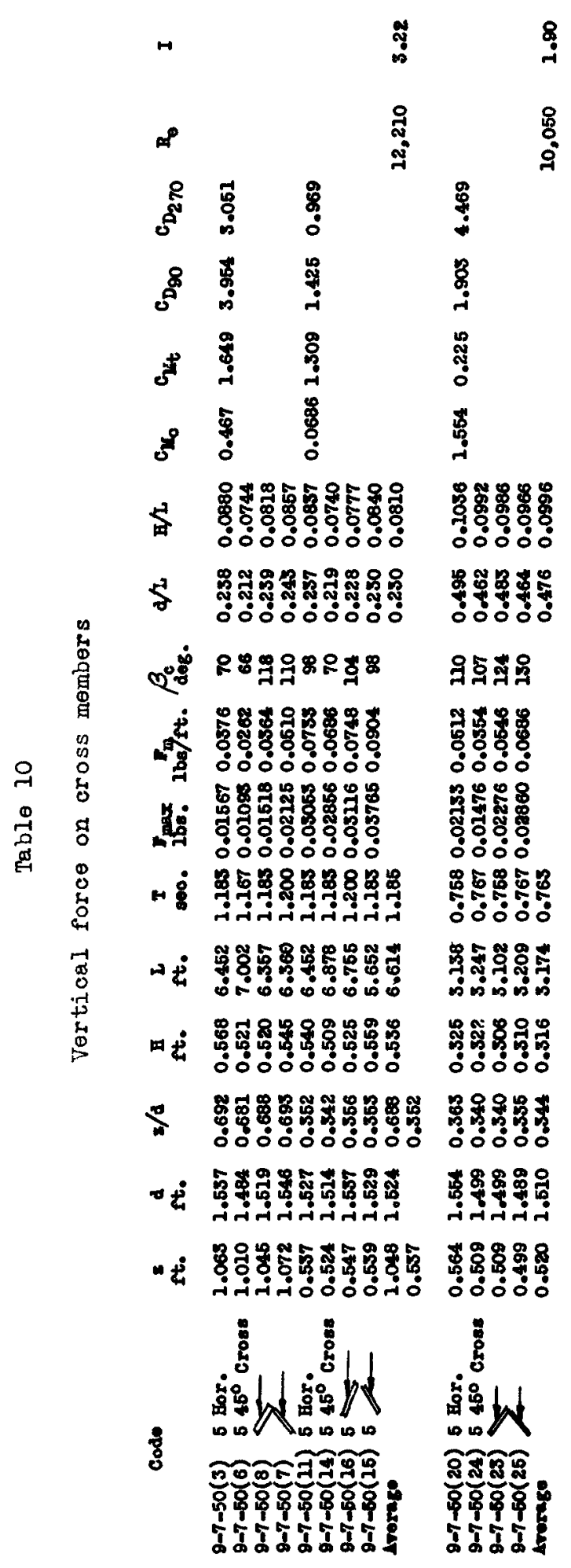




\section{EXPERIMENTAL STUUDIES OF FORCES ON PILES}

The wave height history was obtained from a recording pressure actuated diaphragm type wave meter which was located approximately two feet above the sand botton and adjacent to the plle. Two auxiliary graduated piles were placed seaward of the measuring pile. The measuring p1lo and bracing struoture also were painted with alternate black and white bands, each one foot high. Motion pictures taken from the beach reoorded the surfaoe profile of the waves as they passed the pile. A olook was suspended in the field of view of the camera to provide timing intervals betwoen sucoessive frames of the flim. The wave velooity at the pile was obtained from the distance botwoen the seaward auxiliary pilo and the measuring pile (19.8 feet), and the time intervel of the mave orest travel botween these points. The motion piotures also rocorded wave holghts at the measuring pile. Trough and orest olevations of each wave were obtained from the intersection of the water profile wl th the graduated vertioal piles. The record from the wave moter also gave wave heights and periods.

Analysis of deta: The analysis as presented previously in this paper 1noludes the two resistance terms that oontain $C_{D}$ and $C_{M}$, and also the phase angle relationship, $\beta$, botween the two resistanoe terms. In the analysis of the field pile results, the timing aoouraoy was not proofse onough to determine the time ocmparison botweon the water surface profilo and the moment history.

The data and results ware obtained for waves in rarious oonditions depending on the stage of the tide. Some date were obtained with the pilo in a foam line shoreward of the breaker. Other data wero obtainod with the pile in the smooth unbroken swell seaward of the breaker. The data have boen segregated with respoet to the wave oondition at the pile into the following groups: (1) foam lines (2) foam line inmodiately shoreward of the breaker points (3) breaker, (4) sharp peaked owoll at inoipiont breaks (5) sharp peaked swoll immediately seaward of the breiker point; and (6) swoll somo distanoe soaward of the broaker point. The data aro summarizod in Tablo 11.

The wave force, which 18 actually a diatributed foroe extending from the ooean bottom to the water surface, was rooorded as an equivalont foroe at the calibration point. By multiplying the reoorded foroe by the oalibration-point lever-arm (9 feet 8 inohes) the total moment of the wave foroe about the bottom hingo was doterminod. Then the maximum foroe exists (approximately at the time the wave orest passes the pile), the oontrold of the wave foroe was assumed to be looated near the moan height of the wave. This location of the oentrold was ostimated by oonsidering the horizontel oomponent of the partiole motion as observed in model studies. By ocmputing the wave force at the mean wave helght, as dofined above, the data wore found to be reasonably oonsistent. The ralues obtained from the oomputation indicato that waves of a givon sise and hape $\mathrm{All}$ oxert the same foroe at the oentroid independent of meter-lovel ohanges over the range onoountered in the tests, although the moment about the hinge point variod considerably due to variation of the of footive lever arm as the water dopth ohanged. A graph of the ware foroo at moan mare hoi ght is shown in Fig. 15. 


\section{COASTAL ENGINEERING}

Table 11

Test date on field pile

\begin{tabular}{|c|c|c|c|c|c|c|c|c|c|c|}
\hline $\begin{array}{l}\text { waVs } \\
\text { No. }\end{array}$ & $\begin{array}{l}\text { WAVE } \\
\text { TMPT:* }\end{array}$ & $\begin{array}{c}\text { WAVE } \\
\text { KEIGED } \\
\text { PI } \\
\text { Pt. }\end{array}$ & $\begin{array}{l}\begin{array}{c}\text { MnVe } \\
\text { FERICD }\end{array} \\
T \\
\text { sec. }\end{array}$ & $\begin{array}{c}\text { WA E } \\
\text { VLOCITY } \\
\text { (WEASURED) } \\
c_{\hat{f}} \\
\text { st. } / \text { soo. }\end{array}$ & $\begin{array}{l}\text { LL. VAI ILN } \\
\text { OF } \\
\text { CREBT ON } \\
\text { PILE } \\
\text { Bo } \\
\text { Ft. }\end{array}$ & $\begin{array}{c}\text { SLLVATICY } \\
\text { OF } \\
\text { TPCUGh ON } \\
\text { PILI } \\
\text { st. } \\
\text { Ft. }\end{array}$ & $\begin{array}{l}\text { STILL } \\
\text { WRTER } \\
\text { LEVEL } \\
d-s_{t}+\frac{5}{3} \\
6 t .\end{array}$ & 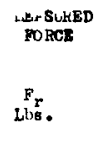 & $\begin{array}{c}\text { TOThL } \\
\text { MONGST } \\
\text { Y } \\
\text { Et-Lbs. }\end{array}$ & $\begin{array}{c}\text { COEFTIC IEHT } \\
\text { OF } \\
\text { DRAG CD }\end{array}$ \\
\hline $\begin{array}{l}1 \\
2 \\
8 \\
4 \\
5 \\
5 \\
7 \\
8\end{array}$ & $\begin{array}{l}\mathrm{F} \\
\mathrm{pL} \\
\mathrm{PL} \\
\mathrm{PL} \\
\mathrm{PL} \\
\mathrm{PL} \\
\mathrm{PL} \\
\mathrm{PL}\end{array}$ & $\begin{array}{l}4.6 \\
4.5 \\
4.2 \\
4.2 \\
4.0 \\
3.8 \\
3.6 \\
3.5\end{array}$ & $\begin{array}{r}10.7 \\
12.1 \\
11.7 \\
9.3 \\
8.3 \\
12.0 \\
7.7 \\
10.3\end{array}$ & $\begin{array}{l}-18.8 \\
17.8 \\
17.5 \\
15.5 \\
17.6 \\
15.8 \\
15.7\end{array}$ & $\begin{array}{l}8.0 \\
8.0 \\
8.0 \\
7.5 \\
7.4 \\
7.0 \\
5.8 \\
6.9\end{array}$ & $\begin{array}{l}3.4 \\
3.5 \\
3.8 \\
3.4 \\
3.4 \\
3.4 \\
2.2 \\
3.4\end{array}$ & $\begin{array}{l}5.20 \\
5.00 \\
4.83 \\
4.20 \\
4.75 \\
4.93 \\
3.40 \\
4.57\end{array}$ & $\begin{array}{l}87 \\
57 \\
64 \\
64 \\
34 \\
51 \\
53 \\
33 \\
\end{array}$ & $\begin{array}{l}562 \\
652 \\
825 \\
629 \\
330 \\
496 \\
515 \\
320 \\
\end{array}$ & $\begin{array}{l}1.05 \\
1.71 \\
1.34 \\
0.65 \\
1.59 \\
1.62 \\
1.46 \\
\end{array}$ \\
\hline 9 & TL-B & 4.1 & 12.1 & 16.1 & 7.4 & 3.3 & 4.67 & 48 & 476 & 1.91 \\
\hline 10 & $8-F L$ & 4.8 & 5.3 & 20.1 & 8,5 & 3.7 & 5.10 & 51 & 496 & $\begin{array}{r}.59 \\
\end{array}$ \\
\hline 11 & 8 & 5.0 & 10.1 & 21.8 & 8.2 & 3.2 & 4.87 & 55 & 535 & $0.4 \mathrm{~S}$ \\
\hline 12 & B & 4.8 & 12.2 & 23.5 & 8.3 & 3.5 & 4.60 & 57 & 652 & 0.63 \\
\hline 13 & 8 & 3.9 & 11.2 & 14.9 & 5.7 & 2.8 & 4.20 & 32 & 310 & 1.05 \\
\hline 14 & 8 & 3.8 & 10.5 & 18.7 & 7.0 & 5.1 & 4.40 & 27 & 200 & 0.75 \\
\hline 15 & $B$ & 3.8 & 8.4 & 17.9 & 6.4 & 2.8 & 4.00 & 34 & 350 & 0.91 \\
\hline 15 & 8 & 3.3 & 11.0 & 14.4 & 5.2 & 1.8 & $3.0 n$ & 28 & 279 & 1.31 \\
\hline $\begin{array}{l}17 \\
18\end{array}$ & $\begin{array}{l}8 \\
8 \\
\end{array}$ & $\begin{array}{l}3.3 \\
3.0\end{array}$ & 10.5 & 14.2 & $\begin{array}{l}5.7 \\
5.5\end{array}$ & $\begin{array}{l}3.4 \\
3.5\end{array}$ & $\begin{array}{r}4.50 \\
4.50\end{array}$ & $\begin{array}{l}25 \\
25\end{array}$ & $\begin{array}{l}225 \\
226 \\
\end{array}$ & 1.28 \\
\hline 18 & $3 P-8$ & 3.4 & 11.0 & 14.8 & 5.8 & 2.4 & 3.53 & 17 & 155 & 0.85 \\
\hline 20 & $B P-\beta$ & 3.3 & 10.8 & 15.5 & 7.0 & 3.7 & 4.80 & 19 & 185 & 0.88 \\
\hline 21 & SP $\rightarrow$ & 3.5 & 9.0 & 14.4 & 6.0 & 2.7 & 3.80 & 13 & 124 & 0.64 \\
\hline 22 & SP-8 & 2.5 & 15.1 & 14.3 & 5.0 & 2.7 & 3.47 & 3 & 38 & 0.39 \\
\hline 23 & 6P $-\mathrm{A}$ & 2.0 & 8.5 & 15.9 & 428 & 2.8 & 3.47 & 4 & 43 & 0.57 \\
\hline 24 & 89 & 4.5 & - & $\cdots$ & 7.8 & 3.5 & 4.80 & 5 & 46 & - \\
\hline 25 & $8 P$ & 3.7 & $\cdots$ & $\cdots$ & 6.2 & 2.5 & 3.73 & 12 & 113 & - \\
\hline $\begin{array}{l}25 \\
27\end{array}$ & $\begin{array}{l}\text { BP } \\
8 P\end{array}$ & $\begin{array}{l}3.8 \\
3.5\end{array}$ & $\begin{array}{l}\text { I2.1 } \\
12.1\end{array}$ & 18.8 & 7.4 & $\begin{array}{l}3.8 \\
3.4\end{array}$ & $\begin{array}{r}4.80 \\
4.57\end{array}$ & 17 & $\begin{array}{l}\text { I66 } \\
109\end{array}$ & 0.44 \\
\hline 28 & SP & 5.5 & $\begin{array}{l}12.1 \\
10.8\end{array}$ & 14.8 & $\begin{array}{l}5.9 \\
8.0\end{array}$ & $\begin{array}{l}3.4 \\
2.7\end{array}$ & $\begin{array}{l}2.67 \\
3.70\end{array}$ & 14 & $\begin{array}{l}109 \\
134\end{array}$ & 0.68 \\
\hline 29 & $8 P$ & 3.5 & 9.1 & 14.8 & 5.8 & 3.3 & $\$ .70$ & 8 & 62 & 0.26 \\
\hline 30 & $8 P$ & 8.1 & 13.0 & 17.7 & 6.8 & 8.7 & 4.75 & 18 & 175 & 0.78 \\
\hline 31 & $8 P$ & 8.1 & 10.0 & 14.2 & 5.8 & 2.8 & 3.85 & 10 & 93 & 0.49 \\
\hline 32 & BP & 3.0 & 11.0 & 15.5 & 6.5 & 5.6 & 4.87 & 9 & 88 & 0.46 \\
\hline 33 & sp & 2.9 & 10.3 & 13.0 & 5.4 & 2.5 & 5.47 & 8 & 75 & 0.60 \\
\hline $\begin{array}{l}34 \\
35\end{array}$ & $\begin{array}{l}8 P \\
g P\end{array}$ & $\begin{array}{l}2.8 \\
2.7\end{array}$ & 11.7 & 14.8 & $\begin{array}{l}8.1 \\
5.0\end{array}$ & $\begin{array}{l}5.3 \\
5.3\end{array}$ & $\begin{array}{l}4.23 \\
4.20\end{array}$ & $\begin{array}{l}8 \\
5\end{array}$ & $\begin{array}{l}83 \\
53\end{array}$ & 0.68 \\
\hline 35 & $S P$ & 2,6 & $=$ & $=$ & 5.9 & 3.3 & 4.50 & 5 & 51 & - \\
\hline 57 & 8 & 5.4 & 9.3 & 15.7 & 5.7 & 3.5 & 4.45 & 9 & 85 & 0.32 \\
\hline 38 & 8 & 3.3 & 9.4 & 12.5 & 5.2 & 2.9 & 4.00 & 15 & 155 & 0.98 \\
\hline 39 & 6 & 5.0 & 8.4 & 18.8 & 6.4 & 3.4 & 4.40 & 12 & 150 & 0.59 \\
\hline 10 & 8 & 2.9 & 4.5 & 16.7 & 5.5 & 3.8 & 4.57 & 5 & 58 & 0.27 \\
\hline 41 & 8 & 2.7 & 9.3 & 14.1 & 5.4 & 3.7 & 5.00 & 8 & 57 & 0.53 \\
\hline 42 & 8 & 2.7 & 7.5 & 15.1 & 6.9 & 3.2 & 4.10 & 7 & 70 & 0.54 \\
\hline 43 & 8 & 2.5 & 9.4 & 13.5 & 5.9 & 3.3 & 4.17 & 7 & 72 & 0.80 \\
\hline 44 & 8 & 2.5 & $=$ & $\overline{-1}$ & 5.9 & 3.4 & 4.23 & 7 & 70 & 0.29 \\
\hline $\begin{array}{l}4 b \\
45\end{array}$ & $\begin{array}{l}8 \\
8\end{array}$ & $\begin{array}{l}2,4 \\
2.4\end{array}$ & $\begin{array}{l}11.8 \\
10.7\end{array}$ & $\begin{array}{l}18.6 \\
18.8\end{array}$ & $\begin{array}{l}5.7 \\
5.0\end{array}$ & $\begin{array}{l}3.3 \\
2.6\end{array}$ & $\begin{array}{l}4.10 \\
5.40\end{array}$ & 8 & $\begin{array}{l}35 \\
75\end{array}$ & $\begin{array}{l}0.29 \\
0.57\end{array}$ \\
\hline 47 & 8 & 2.4 & 8.5 & 16.6 & 6.0 & 3.6 & 4.40 & 8 & 58 & 0.57 \\
\hline 48 & 8 & 24 & 8.2 & 15.8 & 5.6 & 3.2 & $4 . \infty$ & 5 & 45 & 0.43 \\
\hline 48 & 8 & 2.3 & 11.8 & 18,4 & 6.7 & 4.4 & 5.07 & 11 & 108 & 0.86 \\
\hline 50 & 8 & 2.3 & 6.8 & $\rightarrow$ & 5.7 & 3.4 & 4.17 & 3 & 28 & - \\
\hline 51 & 4 & 2.2 & 8.4 & - & 6.9 & 3.7 & 4.45 & 4 & 41 & $\therefore$ \\
\hline $\begin{array}{l}52 \\
53\end{array}$ & 8 & 2,2 & 8.8 & 13.7 & $\begin{array}{l}5.2 \\
5.5\end{array}$ & $\begin{array}{l}8.0 \\
3.4\end{array}$ & $\begin{array}{r}3.73 \\
4.10\end{array}$ & 5 & 50 & 0.74 \\
\hline $\begin{array}{l}53 \\
54\end{array}$ & 8 & $\begin{array}{l}2.1 \\
2.1\end{array}$ & $\begin{array}{r}18.1 \\
7.7\end{array}$ & 18.8 & $\begin{array}{l}5.0 \\
4.9\end{array}$ & 2.8 & 3.50 & $\begin{array}{l}\mathbf{z} \\
2\end{array}$ & $\begin{array}{l}56 \\
15\end{array}$ & $0.2 b$ \\
\hline 65 & 8 & 2.1 & 7.5 & 14.1 & 5.2 & 4.1 & 4.67 & 4 & 35 & 0.08 \\
\hline $\begin{array}{l}55 \\
57\end{array}$ & 8 & $\begin{array}{l}2.1 \\
2.1\end{array}$ & 7.0 & 21.4 & $\begin{array}{l}5.3 \\
6.5\end{array}$ & $\begin{array}{l}3.2 \\
4.4\end{array}$ & $\begin{array}{l}3.90 \\
5.10\end{array}$ & $\begin{array}{l}4 \\
6\end{array}$ & $\begin{array}{l}38 \\
74\end{array}$ & 0.29 \\
\hline 58 & 8 & 2.0 & 11.4 & 12.5 & 4.8 & 2.8 & 3.55 & 3 & 28 & 0.00 \\
\hline $\begin{array}{l}69 \\
80\end{array}$ & $\begin{array}{l}8 \\
8\end{array}$ & $\begin{array}{r}2.0 \\
2.0\end{array}$ & $\begin{array}{l}7.5 \\
5.0\end{array}$ & $\begin{array}{l}19.1 \\
14.4\end{array}$ & $\begin{array}{l}5.2 \\
5.5\end{array}$ & $\begin{array}{l}3.2 \\
3.5\end{array}$ & $\begin{array}{r}3.87 \\
4.17\end{array}$ & 5 & 54 & $\begin{array}{l}0.58 \\
0.86\end{array}$ \\
\hline 51 & 8 & $\begin{array}{l}2.0 \\
2.0\end{array}$ & \begin{tabular}{|l|}
0.0 \\
4.4
\end{tabular} & $\begin{array}{l}14.4 \\
18.8\end{array}$ & $\begin{array}{l}5.6 \\
5.2\end{array}$ & $\begin{array}{l}3.0 \\
4.2\end{array}$ & $\begin{array}{l}4.17 \\
4.87\end{array}$ & 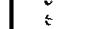 & $\begin{array}{l}47 \\
62\end{array}$ & $\begin{array}{l}0.86 \\
0.88\end{array}$ \\
\hline 62 & 8 & 2.0 & $\overline{10}$ & - & 5.2 & 3.2 & 3.87 & 4 & 35 & $\therefore$ \\
\hline $\begin{array}{l}55 \\
64\end{array}$ & 8 & $\begin{array}{l}1.8 \\
2.9\end{array}$ & 10.0 & 14.8 & $\begin{array}{l}5.8 \\
6.4\end{array}$ & $\begin{array}{l}3.9 \\
4.5\end{array}$ & $\begin{array}{l}4.43 \\
5.13\end{array}$ & $\begin{array}{l}2 \\
3\end{array}$ & $\begin{array}{l}21 \\
41\end{array}$ & 0.45 \\
\hline 65 & 8 & 1.8 & 12.4 & 21.4 & 5.2 & 3.4 & 4.00 & 4 & 23 & 0.24 \\
\hline $\begin{array}{l}65 \\
87\end{array}$ & 8 & $\begin{array}{l}1.8 \\
1.8\end{array}$ & $\begin{array}{r}10.0 \\
8.8\end{array}$ & $\begin{array}{l}11.0 \\
21.7\end{array}$ & $\begin{array}{l}4.5 \\
8.0\end{array}$ & $\begin{array}{l}2.7 \\
4.2\end{array}$ & $\begin{array}{r}3.30 \\
4+80\end{array}$ & s & $\begin{array}{l}25 \\
79\end{array}$ & $\begin{array}{l}0.91 \\
0.88\end{array}$ \\
\hline 68 & 8 & 1.8 & 9.1 & 20.2 & 5.7 & 3.9 & 4.50 & 4 & 36 & 0.45 \\
\hline 88 & 8 & 1.7 & 11.5 & 22.4 & 8.2 & 4.5 & 5.07 & 7 & 69 & 0.88 \\
\hline 70 & 8 & 1.7 & 10.3 & $m$ & 8.4 & 4.7 & 5.27 & 5 & 47 & $=$ \\
\hline $\begin{array}{l}71 \\
72\end{array}$ & 8 & $\begin{array}{l}1.7 \\
1.7\end{array}$ & $=$ & $=$ & $\begin{array}{l}4.4 \\
5.4\end{array}$ & $\begin{array}{l}2.7 \\
3.7\end{array}$ & $\begin{array}{l}3.27 \\
4.27\end{array}$ & 2 & 17 & $=$ \\
\hline $\begin{array}{l}14 \\
73\end{array}$ & 8 & 1.8 & 11.1 & $=$ & $\begin{array}{l}0.4 \\
4.2\end{array}$ & 2.6 & S.18 & I & 4 & $=$ \\
\hline 74 & 8 & 1.6 & 10.8 & $14 *$ & 4.8 & 3.2 & 3.73 & $\tilde{2}$ & 17 & 0.54 \\
\hline
\end{tabular}

* FL (Foam Iine); B (Breaker); SP-B (Sharp peak swell starting to break): FL-B (Broaker with some foam): SP (Sharp peak swell); $S$ (Swoll). 
EXPERIMENTAL STUDIES OF FORCES ON PILES

Table 11 cont'd.

Test data on ireld pilo

\begin{tabular}{|c|c|c|c|c|c|c|c|c|c|c|}
\hline $\begin{array}{c}\mathrm{ratg} \\
\mathrm{No} .\end{array}$ & $\begin{array}{l}\text { WAVE } \\
\text { TYPE }\end{array}$ & $\begin{array}{l}\text { FAVE } \\
\text { HEIGHT } \\
\underset{\text { Ft. }}{\text { B }}\end{array}$ & $\begin{array}{c}\text { WAVE } \\
\text { PERIOD } \\
\\
\text { T } \\
800 .\end{array}$ & 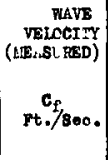 & $\begin{array}{l}\text { ELEVATION } \\
\text { OF } \\
\text { CREST wit } \\
\text { PIL: } \\
s_{o} \\
\text { Ft. }\end{array}$ & $\begin{array}{c}\text { BLEVAT IOT } \\
\text { CF } \\
\text { TROUGI ON } \\
\text { PIIE } \\
s_{+} \\
\text {Ft. }\end{array}$ & $\begin{array}{l}\text { STILL } \\
\text { weVEL } \\
\text { a } s_{+}+\frac{B}{3} \\
d t .\end{array}$ & 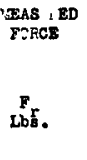 & $\underset{\text { CEETI }}{\text { TOTAL }}$ & $\begin{array}{c}\text { CCEFFIC IE.JT } \\
\text { OF } \\
\text { DRAG } C_{D}\end{array}$ \\
\hline $\begin{array}{c}75 \\
76 \\
77 \\
78 \\
79 \\
80 \\
81 \\
82 \\
83 \\
84 \\
85 \\
86 \\
87 \\
88 \\
88 \\
90 \\
91 \\
92 \\
93 \\
94 \\
93 \\
96 \\
97 \\
98 \\
99 \\
100 \\
101\end{array}$ & $\begin{array}{l}5 \\
8 \\
8 \\
8 \\
8 \\
8 \\
8 \\
8 \\
8 \\
8 \\
8 \\
8 \\
8 \\
8 \\
5 \\
5 \\
5 \\
8 \\
5 \\
5 \\
8 \\
8 \\
5 \\
8 \\
8 \\
5 \\
8\end{array}$ & $\begin{array}{l}1.6 \\
1.6 \\
1.8 \\
1.6 \\
1.5 \\
1.5 \\
1.55 \\
1.55 \\
1.44 \\
1.4 \\
1.4 \\
1.4 \\
1.3 \\
1.3 \\
1.3 \\
1.5 \\
1.3 \\
1.3 \\
1.2 \\
1.2 \\
1.2 \\
1.2 \\
1.2 \\
1.11 \\
1.0 \\
1.0 \\
1.0\end{array}$ & 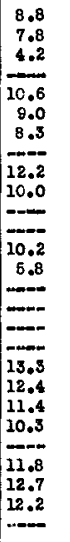 & 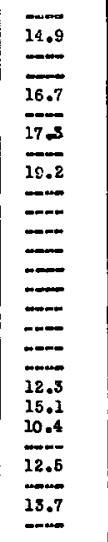 & $\begin{array}{l}5.2 \\
5.3 \\
5.5 \\
5.4 \\
5.3 \\
5.0 \\
4.4 \\
5.1 \\
4.2 \\
5.8 \\
5.4 \\
5.0 \\
4.7 \\
5.5 \\
6.0 \\
6.0 \\
5.8 \\
5.0 \\
4.5 \\
5.8 \\
4.9 \\
6.0 \\
4.7 \\
3.9 \\
4.7 \\
3.7 \\
4.3\end{array}$ & $\begin{array}{l}3.6 \\
3.7 \\
3.9 \\
3.8 \\
3.8 \\
3.5 \\
2.9 \\
3.6 \\
2.8 \\
4.4 \\
4.0 \\
4.5 \\
3.4 \\
4.2 \\
4.7 \\
4.7 \\
4.3 \\
3.7 \\
3.4 \\
4.8 \\
5.7 \\
4.8 \\
3.5 \\
2.8 \\
3.7 \\
2.7 \\
3.6\end{array}$ & $\begin{array}{l}4.13 \\
+.23 \\
4.13 \\
4.35 \\
4.30 \\
4.00 \\
3.40 \\
4.10 \\
3.27 \\
4.60 \\
4.47 \\
4.57 \\
3.83 \\
4.63 \\
5.13 \\
5.13 \\
4.73 \\
4.13 \\
5.80 \\
5.00 \\
4.10 \\
5.17 \\
8.93 \\
3.17 \\
4.03 \\
3.03 \\
3.83\end{array}$ & $\begin{array}{l}3 \\
3 \\
3 \\
3 \\
2 \\
1 \\
1 \\
3 \\
3 \\
2 \\
4 \\
3 \\
2 \\
2 \\
3 \\
6 \\
4 \\
3 \\
2 \\
3 \\
2 \\
5 \\
2 \\
1 \\
1 \\
2 \\
1\end{array}$ & $\begin{array}{r}30 \\
33 \\
27 \\
33 \\
19 \\
5 \\
14 \\
33 \\
29 \\
21 \\
37 \\
34 \\
89 \\
17 \\
29 \\
48 \\
37 \\
29 \\
22 \\
29 \\
19 \\
34 \\
22 \\
12 \\
10 \\
17 \\
10\end{array}$ & 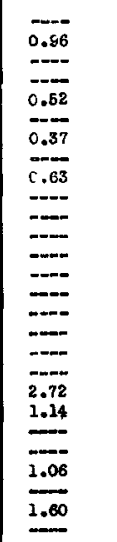 \\
\hline $\begin{array}{l}102 \\
108 \\
704 \\
103 \\
200 \\
207\end{array}$ & $\begin{array}{l}8 \\
8 \\
8 \\
8 \\
8\end{array}$ & $\begin{array}{l}0.9 \\
0.8 \\
0.8 \\
0.7 \\
0.7 \\
0.6\end{array}$ & $\frac{9.8}{=}$ & $\frac{18.5}{ב}$ & $\begin{array}{l}3.8 \\
3.2 \\
3.4 \\
4.9 \\
4.8 \\
5.0\end{array}$ & $\begin{array}{l}2.7 \\
4.4 \\
4.8 \\
4.2 \\
3.9 \\
4.4\end{array}$ & $\begin{array}{l}3.00 \\
4.53 \\
4.87 \\
4.43 \\
4.13 \\
4.00\end{array}$ & $\begin{array}{l}1 \\
1 \\
1 \\
1 \\
1 \\
2\end{array}$ & $\begin{array}{r}8 \\
13 \\
12 \\
10 \\
8 \\
18\end{array}$ & ב.8. \\
\hline
\end{tabular}

* S (Swell). 
One feature beoomes apparent in reviewing the data that pernits a comparison between the model results and the field test results. the majority of the fleld test conditions were obtained with samll ratios of the pile diameter to the wave hoight, and with small ratios of the water depth at the pile to the wave length. Under these conditions, the phase angle as given by Equation (15) approaches zero and the maximum monent of Equation (9) oocure when the time angle, $\theta$, is zero.

Equation (9) for a pile hinged at the bottom then reduces to

$$
u_{\max }=\rho \frac{\mathrm{D} \mathrm{H}^{2} \mathrm{~L}^{2}}{\mathrm{~T}^{2}} \mathrm{c}_{\mathrm{D}} \mathrm{k}_{3}
$$

$k_{3}$ is introduoed as a refinement of $k_{3}$ to inolude an approximation of volooity distributions in a wave of finite height in shallow water: that 18 ,

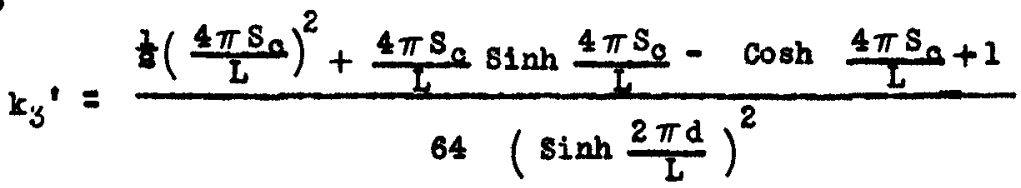

where $d=s_{t}+1 / 3$ I (assumed st1ll-water level)

$s_{0}=$ mave orest elevation above the bottom

$S_{t}=$ wave trough elevation above the bottom

I - wave helght

Por small values of $\mathrm{d} / \mathrm{L}, \operatorname{Sinh} 4 \pi \mathrm{S}_{0} \mathrm{~L} 1 \mathrm{~s}$ approximated by $4 \pi \mathrm{S}_{0} / \mathrm{L}$, and Sinh $2 \pi \mathrm{d} / \mathrm{L}$ is approximated by $2 \pi \mathrm{d} / \mathrm{L}$. These epproximations result In

$$
\mathbf{k}_{3}=\frac{3}{32} \frac{s_{0}}{d}
$$

and

$$
C_{D}=\frac{s 2}{s} \frac{y_{n x} \mathrm{~T}^{2} \mathrm{~d}}{\rho \mathrm{DH}^{2} \mathrm{~T}^{2} \mathrm{~S}_{0}}
$$

As the wave relooity 18 related to the length and period by $C=L / T$, we find that

$$
c_{D}=\frac{32}{3} \frac{s_{n n} c^{2} d}{\rho D H^{2} s_{0}}
$$

111 variables on the right of do of Equation (22) mero measured and $D_{D}$ then oomputed. $C_{D}$ is a drag ooeffiolent whioh depends upon the state of the disturbanos of the wave motion due to the movement of the wave past the pile. For shallow-mater waves, the voloolty distribution from the orest of the wave to the bottom is a function of the ratio of wave helght to water depth, and 18 essentially independent of the wave length or period. The resulting moment on the pile, and henoe $C_{D}$, are funotions of this ratio, $H / d$. The results are shom in $F 1 \mathrm{~g} .16$ on this basis, with segregation of the results aocording to wave type. The field pile results were obtained for wave oonditions of $\mathrm{d} / \mathrm{L}$ loss than 0.06 , with the mafority of the waves oharacterised by $d / L$ less than 0.03 . 
EXPERIMENTAL STUDIES OF FORCES ON PILES
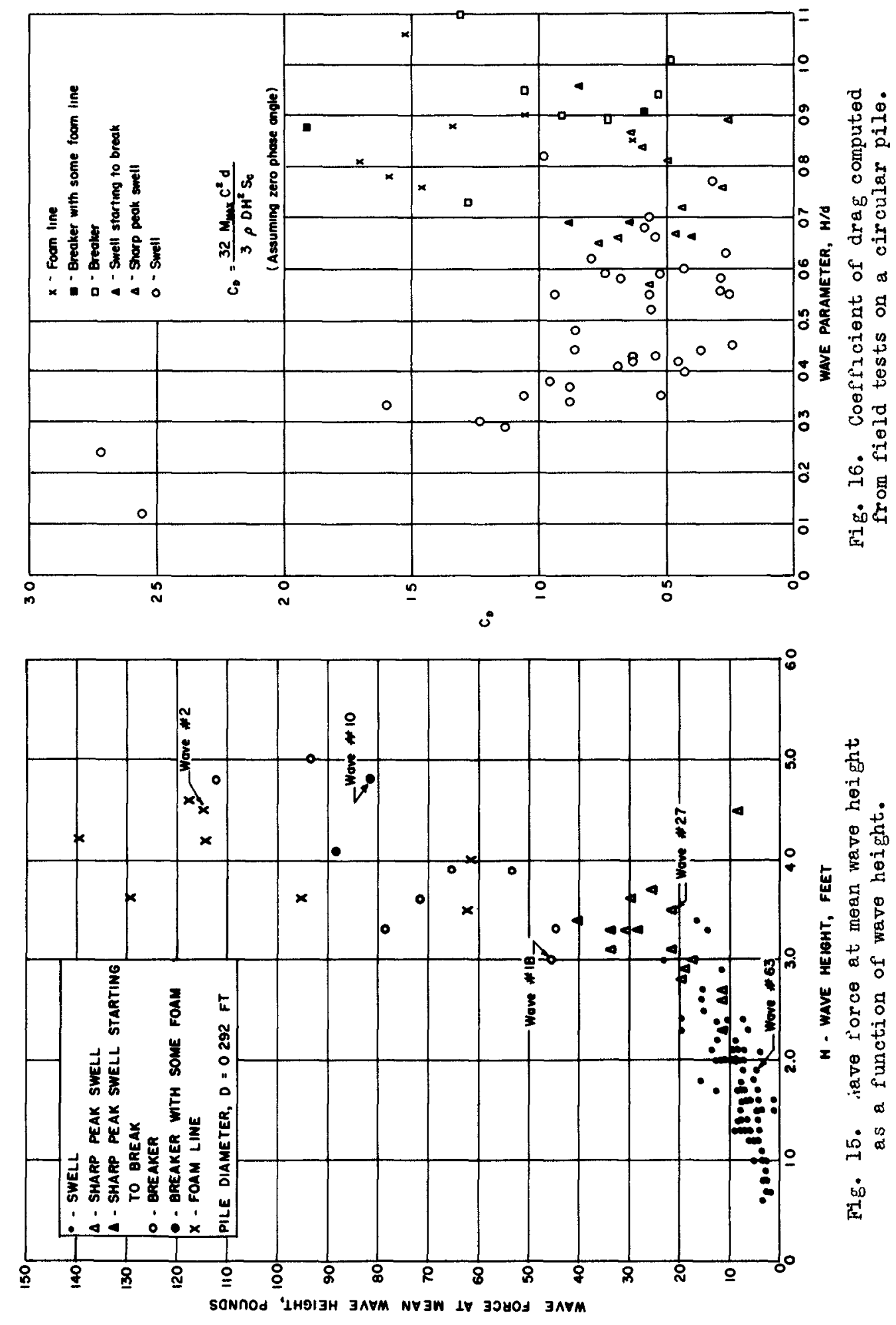
The soatter of the results refleots the aooursoy of the data and the acouraoy of the assumptions of Equation (22), $C_{D}$ is oomputed from Equation (22) which contains the square of the wave velooity and the square of the wave hoight. Small disorepanoies of these variables may produce appreoiable differenoes in $C_{D}$. The maximum moment was obtained from the foroe, which was measured to within one pound. Many of the measured foroes wore from one to fiwo pounds. Some soatter of result: is nooessarily expootod. vations.

Enough date wore taken to permit the following general obser-

1) Foam lines and breakers produce higher values of $C_{D}$ than unbroken swolls.

2) For ralues of $\mathrm{H} / \mathrm{d}$ greater than 0.4 , an average value of $C_{D}$ oqual to 0.50 best represents the results.

3) For values of $\mathrm{H} / \mathrm{d}$ less than $0.4, \mathrm{C}_{\mathrm{D}}$ becomes larger than 0.50 . The assumptions of Equation (22) booome invalid in this range of $\mathrm{H} / \mathrm{d}$.

A direot oomparison of the model test results with the field test results cannot be made. The same range of the govorning parameters was not covered in the two series of tests, partioularly the ranges of $\mathrm{d} / \mathrm{h}$ and $\mathrm{H} / \mathrm{d}$. In FIg. 16 drag ooeffioients of 1.0 to 2.5 are shown for values $\mathrm{H} / \mathrm{d}$ betwoen 0.4 and 0.1 . These magnitudes of the drag coeffioients are in the same range as those obtained from the model studies. However, the values of $d / L$ of the fleld tests were not the same as the model tests. As mentioned in the model test summary, complote oorrelations inoluding all defining paramotors have not yot been attained. Wo attempts have been made to oarry the field results beyond Fig. 16.

\section{CONCLUSIONS}

The analysis of foroes and moments on piles as summarized horoin contalns two ooeffioients whioh must be determined experimentallys the ooeffioient of mass and the coeffloiont of drag. The results so far obtainod indicate that the theoretical value of 2.0 for the ooeffiolent of mass is adequate for oomputing the foroes on oiroular piling. For the ooefficient of drag, however, additional results are needed with a largo range of the variables of pile diameter, wave hoight, wave length, and water depth.

The results show that moments measured about a single hinge point will suffioe in establishing the magnitudes of the coeffioients. The moment distribution from cooffioionts obtained from moments about a bottom hinge point agroe with mosourod moment distributions.

Noasured moments on piles of oross-seotional shape othor than oiroular show ooeffioients which are a function of the shape of the pile. Steady-state drag ooeffioients oan not be used as drag cooffioients in the analysis of poriodio motion. 


\section{EXPERIMENTAL STUDIES OF FORCES ON PILES}

Results of the interferenoe effects of rows of olroular piling, while limited in scope, indioated that for oloaranoes groater than $1 \frac{7}{8}$ pile diameters the interforenoe offeots are negligible. Moments on oenter piles of a row are inoreased as ocmpared to moments on an iso-

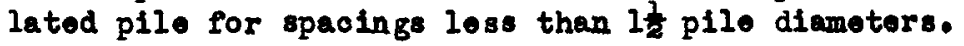

Yoments on oiroular piles arranged in columns are decreased as compared to moments on an isolated pilo. No limits woro dotermined at which the moment became independent of the spaoing.

\section{RECOMAENDA TIONS}

The following experiments on model piles are recommended for comparison purposes with theoretioal work and prototype tests.

1. Measurement of weve foroe distribution on single piles of various diamotors aro noeded in order to compare with Equations (4) and (8).

2. Bxperimente with a coater number of wave conditions on oiroular pilos, H-sootions, flat plates and varlous other objeots are neoded in order to establish the relationship of the oooffiolents of drag and ss to the were oharaoteristios.

3. Investigation should be made of the mathematical theories pertaining to piles and other objeots subjeot to were aotion with respeot to foroe, wave rofleotion, ware diffraction and flow oonditions in the Fioinity of the objeot.

4. Investigation should be made of breaking waves on model struotures inoluding the development of for oe reoording equipment.

\section{ACK HOWLEDGMEN IS}

The above investigations wore sponsored by the Offloe of Naval Research, Bureau of Yards and Doaks, The Celifornia Company, and International Marine Platforms, Ino.

\section{REF ERENCES}

Morison, J.R. (1960a) Moment distribution on stoppod oalsson, Sories 35, Issue 1, IER, University of Callf., Berkeloy, Calif.

Morison, J.R. (1950b) Moment distribution exorted by waves on piling; Sories 36, Issue 2, IER, University of Calif., Borkeley, Calif.

Morison, J.R., (19500) The foroes exorted by waves on marine struotures Series 36, Is sue 3, IRR, University of Callf., Berkeley, Calif.

Morioon, J.R., O'Brien, M.P., Johnson, J.W. and Sohaaf, S.A. (1860) The foroes exerted by surface waves on piles, Potroleum Trans. AIN , vol. 189, pp. 149-164. 


\section{COASTAL ENGINEERING}

O'Brien, M.P., and Morison, J.R. (1950) The forces exerted by waves on objects, Serios 3, Issue 310, IKR, University of Calff, Berkeley, celif.

Snodgrass, F.E., Rice, E.R., and Hall, M. (1961) Wave foroes on piling (Monteroy field test); Series 35, Issue 4, IER, University of Calif., Borkeley, Calif.

Stokes, Sir G.G. (1901) On the theory of oscillatory wares, Math. and Physical Papors, vol. V, Cambridge Univeraity Pross

\section{APPENDIX}

Correotions to "Design of PIling". Chapter 28, Prooevdings of the First Conference on Coastel Engineering:

Page 267, Iine 13

$$
C_{M}=2.0 \text { (use theoretical value of } 2.0 \text { ) }
$$

Page 257, line 24

$$
\begin{aligned}
\mathbf{u}_{z} & =\rho \frac{\mathrm{E}^{2} \mathrm{~L}^{2} \mathrm{D}}{\mathrm{T}^{2}}\left\{ \pm \mathrm{C}_{\mathrm{D}} \mathrm{K}_{2} \cos ^{2} \theta+\frac{\pi D}{4 \mathrm{H}} \mathrm{K}_{1} \mathrm{C}_{\mathrm{M}} \sin \theta\right\} \\
& =\frac{(2.0)(10)^{2}(462)^{2}(1.5)\left\{+1.6(0.0837)(0.9848)^{2}\right.}{(10)^{2}} \\
& \left.+\frac{\pi}{4} \frac{1.5}{10}(0.395)(2.0)(0.1737)\right\} \\
& =612,000\{0.1294+0.0162\}=89,000 \text { ft. 168. }
\end{aligned}
$$

Page 258, line 16,

$$
\begin{aligned}
M & =\rho \frac{E^{2} L^{2} D}{T^{2}}\left\{\frac{\pi D}{4 I} I_{1} c_{M}(1)\right\} \\
& =\frac{(2.0)(10)^{2}(152)^{2}(6)}{10^{2}}\left\{\frac{\pi}{T} \cdot \frac{6}{10}(0.395)(2.0)\right\} \\
& =916,000 \text { ft. 1bs. }
\end{aligned}
$$

